\title{
Title: An exergoeconomic-based parametric study to examine the effects of active and passive energy retrofit strategies for buildings
}

\author{
Iván García Kerdann ${ }^{\mathrm{a},}{ }^{\star}$, Rokia Raslan ${ }^{\mathrm{b}}$, Paul Ruyssevelta, David Morillón Gálvez ${ }^{\mathrm{c}}$ \\ a Energy Institute, University College London, 14 Upper Woburn PI, London, WC1H ONN, U.K. \\ ${ }^{\mathrm{b}}$ Environmental Design and Engineering, University College London, 14 Upper Woburn PI, London, \\ WC1H ONN, U.K. \\ c Departamento de Mecánica y Energía, Instituto de Ingeniería, Universidad Nacional Autónoma de \\ México, México, México
}

\begin{abstract}
The paper describes a systematic framework that uses exergoeconomic theory integrated into 'building energy retrofit' (BER) design. An exergoeconomic module, based on the SPECO method, has been embedded into 'EXRETOpt', a recently developed retrofit-oriented exergy simulation tool based on EnergyPlus. Both active and passive technologies were analysed using two calibrated archetype non-domestic buildings as case studies (an office and a primary school). A novel cost-benefit indicator which accounts for building exergy destruction cost, retrofit annual capital cost, and project annual revenue is presented. This indicator is employed to account for best exergoeconomic performance technologies and to further develop deep BER packages. Compared to typical practice, exergoeconomics combined with cost-benefit provides a powerful tool for exploration and design improvement of building energy systems. In both cases, final product cost for heating and cooling processes were substantially reduced. In addition, the office case presented improvements in energy use by $67 \%, \mathrm{CO}_{2}$ emissions by $53 \%$, thermal comfort by $22 \%$, exergy destructions by $42 \%$, and the overall building exergy efficiency was improved from $14.8 \%$ to $20.0 \%$. The school case presented similar results with an improvement of building exergy efficiency from $8.2 \%$ to $11.1 \%$, and the potential to generate income due to current government incentives.
\end{abstract}

\section{Keywords:}

exergy; exergoeconomics; building simulation; retrofits; parametric study; cost-benefit analysis. 


\section{Introduction}

\subsection{Energy and exergy in buildings}

In the UK, the non-domestic sector is responsible for $17 \%$ of the country's total energy use (1576.9 PJ) [1]. By 2050, the UK government has set the ambition of reducing national emissions by $80 \%$, where the reduction of primary energy use in buildings will play a major role. However, future projections establish that the sector's footprint will increase by 200 million $\mathrm{m}^{2}$, where $80 \%$ of the current stock (2015) will still be in use [2].

Building energy retrofit (BER) is a strategy that has the potential to significantly reduce sectoral emissions. Driven by current building regulations, common BER practice is still largely reliant on maximizing the thermal quality of the building envelope before HVAC system improvements are introduced. With the current high dependency on high-quality energy sources such as natural gas, oil, and off-site generated electricity, combined with the low thermodynamic efficiency of current building system technologies, new approaches to improve the selection of optimal BER measures are essential. Meggers et.al [3] established that focusing more attention on HVAC systems can provide more flexibility by creating a wider range of design possibilities through the consideration of more energy sources and technologies. Nagy et.al [4] explored the balance between insulation measures and heating system parameters to find optimal supply temperatures. The authors showed that reducing supply temperatures of the heating systems offers more potential to reduce buildings emissions than increasing the envelope insulation thickness.

As Hepbasli [5] noted, the 'Passivhaus' approach and the 'Low-exergy' approach are not mutually exclusive, since several strategies present similarities with the only limitation of the former to only be based on the thermodynamics $1^{\text {st }}$ Law where the latter is based on both the $1^{\text {st }}$ and $2^{\text {nd }}$ Law. As any real thermodynamic process is irreversible, which means that it cannot return to original conditions due to the constant increase of entropy, exergy analysis can be performed to obtain more information on the causes and locations of these irreversibilities. Thus, exergy analysis can therefore be considered a logical approach to be applied in the design and improvement of BER.

Over the last few decades, several studies have been conducted with the aim of developing exergy methods applied to buildings [6-8]. Further studies have also applied exergy analysis for the identification of 'unconventional' opportunities to reduce dependency on high quality fuels and to minimise the gap between the quality of the supply and demand, leading to the 
reduction of primary energy inputs [9-11]. For example, Esen et.al [12] presented an exergetic analysis of a GSHP working with two horizontal ground heat exchangers (HGHE) at different depths $(1 \mathrm{~m}$ and $2 \mathrm{~m})$. The author demonstrated that, the deeper heat exchanger $(2 \mathrm{~m})$ had a better thermodynamic performance ( $\psi=56.3 \%$ compared to $\psi=53.1 \%$ ) due to a smaller temperature lift, indicating that small variations in source temperature leads to significant reductions in primary exergy destructions. In addition, a number of studies reviewed the impact of a range of HVAC systems on building exergy performance [13-15]. Although several suggestions for improvement were presented, a main limitation highlighted the lack of appropriate economic appraisal which may lead to financially infeasible solutions.

\subsection{Economics and Exergoeconomics in buildings}

In BER practice, economics plays a substantial role in the decision making process where practitioners have to determine projects that minimize life cycle costs while also maximising energy savings. Life cycle cost takes into account all costs 'incurred' during the project lifespan, such as capital, operation, maintenance, and disposal. This method is useful in comparing designs with similar energy performance but with disparate economic indicators. Other useful indicators include 'Simple Payback', 'Discounted Payback', 'Profitability Index', 'Net Present Value', and 'Internal Rate of Return'. Esen et.al [16] applied these indicators to compare different conventional HVAC with a GSHP. Results showed that improved COPs combined with reduction in capital cost have made GSHP to become a more cost-effective solution in the past decade. Nevertheless, recent research has been improving these typical methods to achieve less uncertain results $[17,18]$. As many researchers suggest [19-21], exergy represents the real value of an energy source, thus it should be the only rational basis for economic evaluation. Müller et.al [22] suggest that prices are a reflection of the exergy content of the specific energy carrier and the share of technology investment increases when low exergy sources are required.

Exergy analysis combined with microeconomics may potentially help improve BER design by locating the sources of inefficiencies and estimating monetary expenditure incurred as a result of exergy destructions. This combined method is known as exergoeconomics, and is commonly used in power plants and chemical processes for system optimisation. While some researchers applied exergoeconomic analysis to buildings [23-32], the analysis is often limited to only a single system design. In addition, these studies also showed that the reference temperature (normally outdoor temperature) is the most sensitive parameter, thus having the biggest effect on thermoeconomic results. 
As the building sector play a fundamental part in achieving sustainable societies, there is a pressing need to rethink the way in which buildings are designed. While the current significant trend in using simulation tools for building energy design, compliance, and operation is not specifically focused on the assessment of BERs, in the past years several toolkits have been developed for this purpose [33]. And although some exergy-based building simulation tools have been created in the past decade [34-36], these lack exergoeconomic evaluation and an orientation to assess retrofit measures.

As such, the objective of this study is to exergoeconomically assess a wide range of active and passive BER measures by applying a novel cost-benefit indicator which accounts for building exergy destruction cost rate, retrofit annual capital cost rate, and project annual revenue rate. This indicator will be used for comparison among BER designs to determine best exergetic and exergoeconomic performance, and to further develop deep-BER designs. For this purpose, the expansion of EXRETOpt [37] (a recently developed retrofit-oriented exergy-based dynamic simulation tool) is necessary through the integration of an exergoeconomic analysis module.

\section{Material and Methods}

\subsection{Simulation-based exergoeconomic framework for analysis of BER}

EXRETOpt is a retrofit-oriented exergy-based tool based on EnergyPlus [38], the details of which are discussed in a previous publication by the authors [37]. For this study, a pythonbased model was developed to perform exergoeconomic calculations within it. The code reads selected hourly outputs from the EnergyPlus/Exergy module and creates new spreadsheets with exergy and exergoeconomic indicators. The expanded tool is capable of providing 350+ thermodynamic and non-thermodynamic indicators. Fig. 1 illustrates the design framework and procedure for the integration of exergoeconomic analysis into BER modelling practice. The diagram also shows the modelling environments utilised at each stage of the framework. 


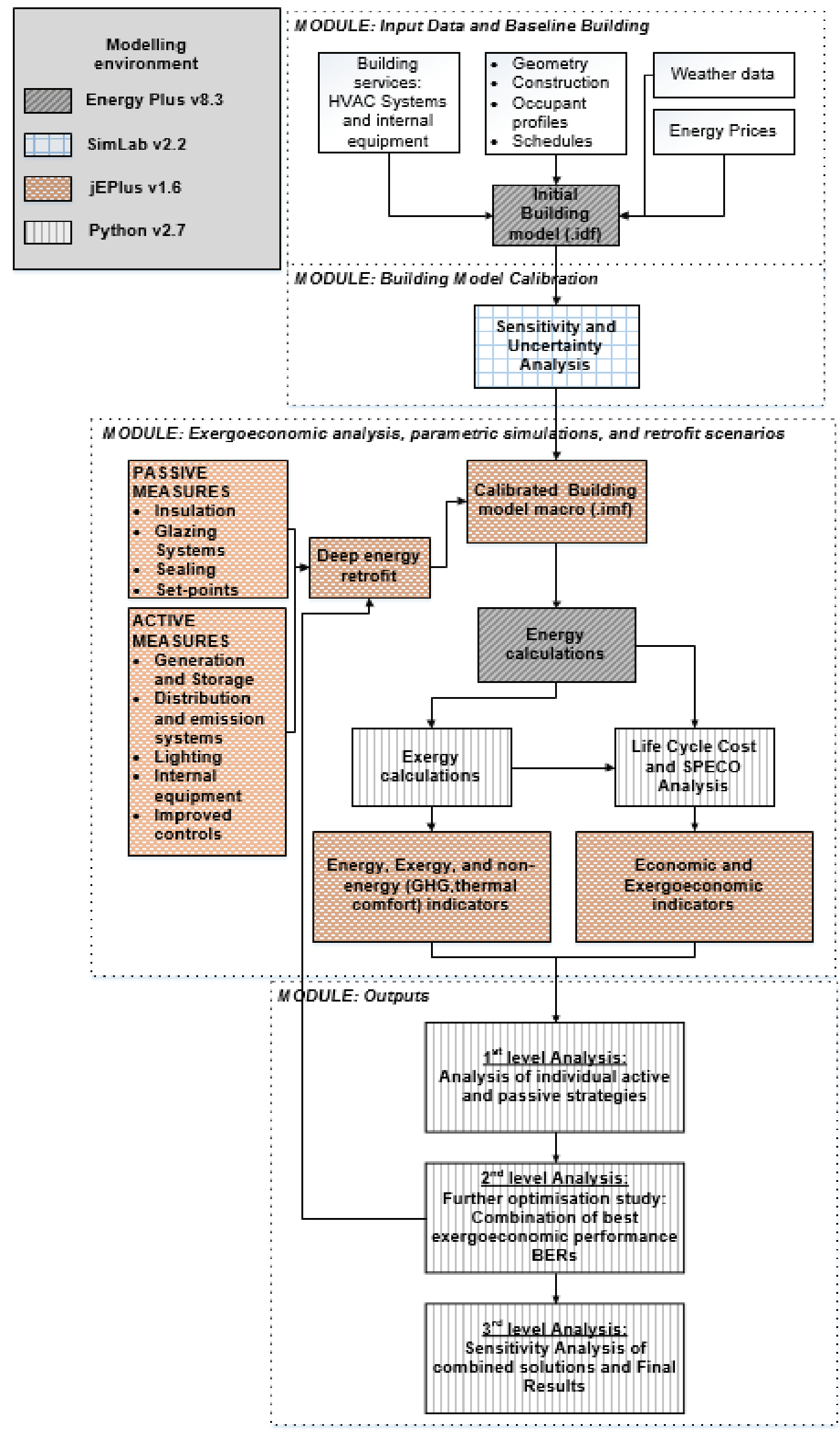

Fig. 1 Design framework for exergoeconomic-based retrofit analysis [37] 
The building thermal exergy method used in the modelling process is mainly based on the developments proposed by Schmidt [7] and Torio [8] and implemented in the IEA ECB Annex 49 [36]. The method utilises an input-output approach based on seven different subsystems to calculate the variables throughout the energy supply chain. Previously, EXRETOpt has implemented these equations for dynamic building simulation by using python scripts. In addition, EXRETOpt is also capable of calculating exergy destructions on the DHW system level, refrigeration, cooking, and all electric-based equipment, thus allowing for a holistic exergy assessment. For electric-based equipment, Table 1 shows the model assumptions for energy and exergy efficiency:

Table 1 Exergy efficiency values for electric-based devices [39]

\begin{tabular}{ccc}
\hline Equipment & $\begin{array}{c}\text { Energy Efficiency } \\
(\mathbf{\%})\end{array}$ & $\begin{array}{c}\text { Exergy efficiency } \\
(\mathbf{\%})\end{array}$ \\
\hline Motors & $80-87$ & $80-87$ \\
Fuel cell system & 33 & 33 \\
CHP & 74 & 31 \\
Solar photovoltaic & $6-25$ & $6-25$ \\
Solar thermal & $10-30$ & $10-30$ \\
Small wind turbines & $20-40[40]$ & $19-29[41]$ \\
Electric battery (lead-acid) & $75-85$ & $75-85$ \\
Pumps & $60-70[42]$ & $58-67[42]$ \\
Fans & $55-80[42,43]$ & $50-68[42,44]$ \\
Resistance space heater & 99 & 6 \\
Lighting fluorescent and LED & 20 & 20 \\
Electric-based catering & 85 & 50 \\
Internal/office equipment & 70 & 70 \\
\hline
\end{tabular}

This holistic method provides comprehensive means by which to understand the interactions between the building envelope and the building energy services. For a better interpretation, thermodynamic assessments typically require an input-output abstraction of all the subsystems that interact in the whole energy process (Fig. 2). The basic formulas for guidance are presented in the following section. 


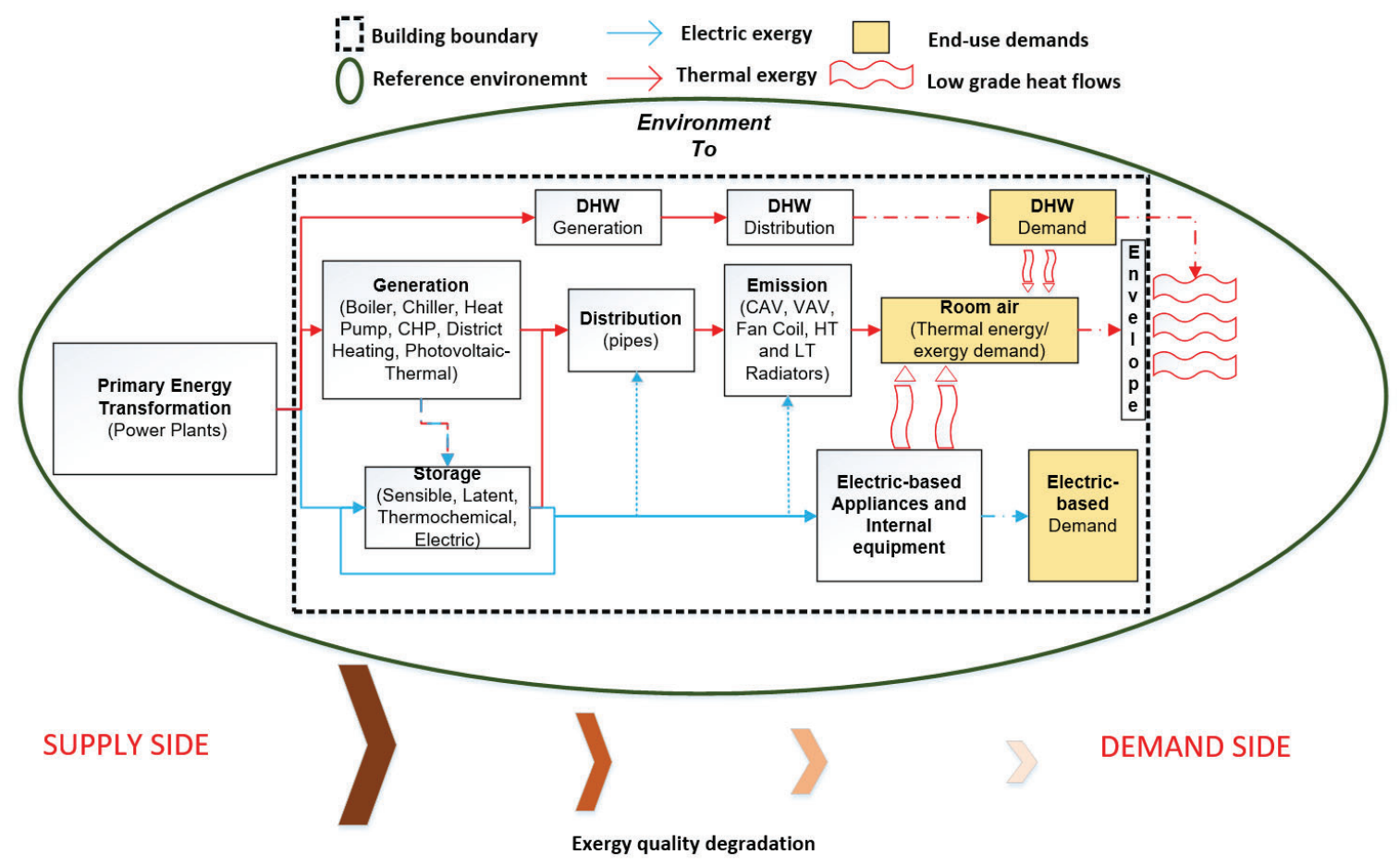

Fig. 2 Energy supply chain and subsystems for exergy calculations. Based on the IEA ECB Annex 49 method calculation.

\subsubsection{Exergy demand and irreversibilities calculation}

The total exergy demand at the building level $E x_{d e m, b u i}$ is obtained by adding all the demands for each end-use:

$E x_{d e m, b u i}=\sum E x_{d e m, e n d}$ use,ith

where $E x_{\text {dem,end use }}$ is the exergy demand by end-use.

After calculating the total demand, the model calculates irreversibilities at each subsystem level. Ex $x_{\text {prim }}$, the exergy input at the primary energy transformation subsystem is analysed and the impact of using different types of energy sources are distinguished as follows:

$\operatorname{Ex}_{\text {prim }}\left(t_{k}\right)=\sum_{i}\left[\frac{\operatorname{En}_{\text {gen }, i}\left(t_{k}\right)}{\eta_{\text {gen }, i}\left(t_{k}\right)} * F_{p, \text { source }, i} * F_{q, \text { source }, i}\right]$ 
where, $E n_{\text {gen }}$ is the energy source used by the building HVAC generation system (chiller, boiler, CHP), $\eta_{\text {gen }}$ is the system efficiency, $F_{p \text {,source }}$ is the is the UK primary energy factor [45] and $F_{q, \text { source }}$ is quality factor of the fuel [36]. These factors are shown in Table 2.

Table 2 Primary Energy Factors and Quality Factors by energy sources [36,45]

\begin{tabular}{|c|c|c|}
\hline Energy source & $\begin{array}{c}\text { Primary energy } \\
\text { factor }\left(F_{p}\right) \\
(\mathbf{k W h} / \mathbf{k W h})\end{array}$ & $\begin{array}{c}\text { Quality factor } \\
\left(F_{q}\right) \\
\text { (kWh_ex/kWh_en) }\end{array}$ \\
\hline Natural gas & 1.11 & 0.94 \\
\hline Electricity (Grid supplied) & 2.58 & 1.00 \\
\hline District Energy ${ }^{1}$ & 1.11 & 0.94 \\
\hline Oil & 1.07 & 1.00 \\
\hline Biomass (Wood pellets) & 1.20 & 1.05 \\
\hline
\end{tabular}

The total exergy destructions $E x_{\text {dest, }}$, are calculated as follows

$E x_{\text {dest }}=E x_{\text {prim }}-E x_{\text {dem, bui }}$

Finally, the building exergy efficiency $\Psi_{b u i}$ is obtained as follows:

$\Psi_{\text {bui }}=\frac{E x_{\text {dem,bui }}}{E x_{\text {prim }}}$

\subsubsection{Exergy analysis of renewable systems}

As technologies considered in this analysis such as photovoltaic panels, solar collectors, hybrid PV/T, and ground/air source heat pumps require a different exergy analysis, the tool was expanded to integrate renewable-based technologies. The equations to incorporate this were based on a comprehensive review of exergy analysis for renewable-based systems undertaken by Torío et.al [46] and described in the calculation method in Appendix A.

\subsubsection{The reference environment}

Although widely discussed, the majority of the research considers the outdoor air as the most appropriate reference environment for the analysis [36]. Pons [47] considers that the dynamism of the reference environment and the time-dependency may not be the best choice. As such, the use of a static reference temperature through the consideration of a linear

\footnotetext{
${ }^{1}$ The District system was assumed to be run by a single-effect indirect-fired absorption chiller with a coefficient of performance (COP) of 0.7 .
} 
combination between entropy generation multiplied by a constant temperature is more appropriate. This presents an advantage, as entropy does not depend on temperature but only on the state of the system. Other authors consider that the dynamism of the 'dead-state' has to be accounted for, where the use of dynamic temperature is more appropriate, especially if dehumidification and cooling processes exist within the building [48-50]. In this study, the dynamic simulation approach is applied.

\subsection{Retrofit measures and cost database}

As building energy efficiency can usually be improved by both passive and active technologies, a comprehensive BER database was compiled. This included active retrofit designs such as HVAC, lighting, and renewable energy generation systems, as well as passive solutions such as envelope insulation, glazing systems, air-leakage improvement, and heating and cooling set points variation. The solutions were implemented by developing individual '.idf files' (EnergyPlus files) combined through the use of the EnergyPlus Macro function, and then 'handled' by jEPlus software [51] to undertake the final simulation. To support the economic analysis, prices must be properly defined. These were obtained from a wide range of databases such as 'Spons' manuals [52, 53], DECC [54], NREL [55], RSmeans [56], webstores [57], and academic publications [58, 59]. As EnergyPlus has the capability to auto-size any equipment, prices are provided per unit (either $\mathrm{kW}$ or by $\mathrm{m}^{2}$ ) since the model automatically calculates the total capital price for either individual or combined measures. The list of technologies, variables, and prices $^{2}$ for all retrofit measures is detailed in Appendix B.

\subsection{Economic and Exergoeconomic analysis}

\subsubsection{Net Present Value (NPV) and Discounted Payback Period (DPB)}

For BER, NPV indicates the present value of an investment based on expected energy savings costs minus the cost of the project, where a positive NPV value represent financial viability. Despite some limitations, especially due to future uncertainty, NPV is the most widely used

\footnotetext{
${ }^{2}$ If prices for some measures were not in local currency (GBP), conversion rates from $25^{\text {th }}$-October-2015 were considered.
} 
technique for BER assessment [18], as it provides a more realistic representation of the future value of money. NPV is calculated as follows:

$N P V_{\text {Nyears }}=-T C I+\left(\sum_{n=1}^{N} \frac{R}{(1+i)^{n}}\right)+\frac{S V_{N}}{(1+i)^{N}}$

where $\mathrm{TCl}$ is initial total capital investment, $R$ is the annual revenue costs (composed by the annual energy cost savings minus the operation and maintenance cost), and $S V$ is the salvage cost or residual value with measures with longer lifespan (we have considered a common rate of $15 \%$ ). In this study, a lifespan $(\mathrm{N})$ of 50 years and a discount rate $(i)$ of $3 \%$ [60] were considered.

DPB provides the number of years to the break-even point by also considering the future value of money. Thus, to calculate DPB period we used the following formula [61]:

$D P B=-\frac{\ln \left[\left((1-(1+i)) *\left(\frac{T C I}{R}\right)\right)+1\right]}{\ln (1+i)}$

\subsubsection{Energy Prices and Incentive Programs}

The economic module considers average fuel prices for the corresponding building size. These were obtained from the government bulletin quarterly energy prices for September 2015 [62] and are shown in Table 3. In addition, an annual energy price escalation was included for all energy sources based on the previous ten years.

Table 3 Energy tariffs in the UK in 2015 (considering $\mathrm{CCL}^{3}$ ) [62]

\begin{tabular}{cc}
\hline Energy source & $\begin{array}{c}\text { Prices } \\
(\boldsymbol{(} / \mathbf{k W h})\end{array}$ \\
\hline Natural gas & 0.030 \\
Electricity (Grid supplied) & 0.121 \\
District Energy & 0.066 \\
Oil & 0.054 \\
Biomass (Wood pellets) & 0.044 \\
\hline
\end{tabular}

\footnotetext{
${ }^{3} \mathrm{CCL}$ is a tax for some energy sources delivered to non-domestic users where the tax aim is to incentivise users to install energy efficient technologies.
} 
Moreover, government incentives that provide financial help to certain 'renewable' and 'low carbon' technologies were included. Depending on the project, this could play a major role in the financial viability of some BER designs. The two main government incentives are: Feedin Tariff (FiT) and the Renewable Heat Incentive (RHI). FiT is a grant scheme that focuses on renewable electricity generation technologies such as $\mathrm{mCHP}$, wind turbines, and photovoltaic panels; while $\mathrm{RHI}$ is a grant scheme focused on the implementation and use of renewable heat, prioritizing technologies such as biomass/biogas heating, heat pumps, and solar collectors. Whilst these incentives are constantly changing, for this analysis we have considered tariffs from October 2015 (Table 4).

Table 4 UK Government subsidies in 2015

\begin{tabular}{cc}
\hline Incentive Schemes Tariff & $\begin{array}{c}\text { Prices } \\
(\mathbf{f} / \mathbf{k W h})\end{array}$ \\
\hline FiT Electricity Exported & 0.048 \\
FiT PV Electricity Generation & 0.059 \\
FiT Wind Electricity Generation & 0.138 \\
RHI Solar Heat Generation & 0.103 \\
RHI GSHP Heat Generation & 0.090 \\
RHI ASHP Heat Generation & 0.026 \\
RHI Biomass Heating Generation & 0.045 \\
\hline
\end{tabular}

\subsubsection{Exergoeconomic module}

When costs are not allocated appropriately, it becomes difficult to assess the actual cost effectiveness of a measure, especially when multiple products exist, as is in the case of buildings [63]. Therefore, the typical economic analysis was expanded to include an exergoeconomic evaluation module. The chosen exergoeconomic method was "SPECO" (specific exergy cost), initially developed by Tsatsaronis [20] and further improved in Lazzaretto and Tsatsaronis [64]. The SPECO method is based on the calculation of exergy efficiencies, exergy destructions, exergy losses, and exergy ratios at a component level. After quantifying the energy and exergy streams through the energy supply chain, a definition of fuel(s) and product(s) for each component has to be constructed where cost balance equations have to be applied. A representation of the analysis can be seen in Fig. 3 . 


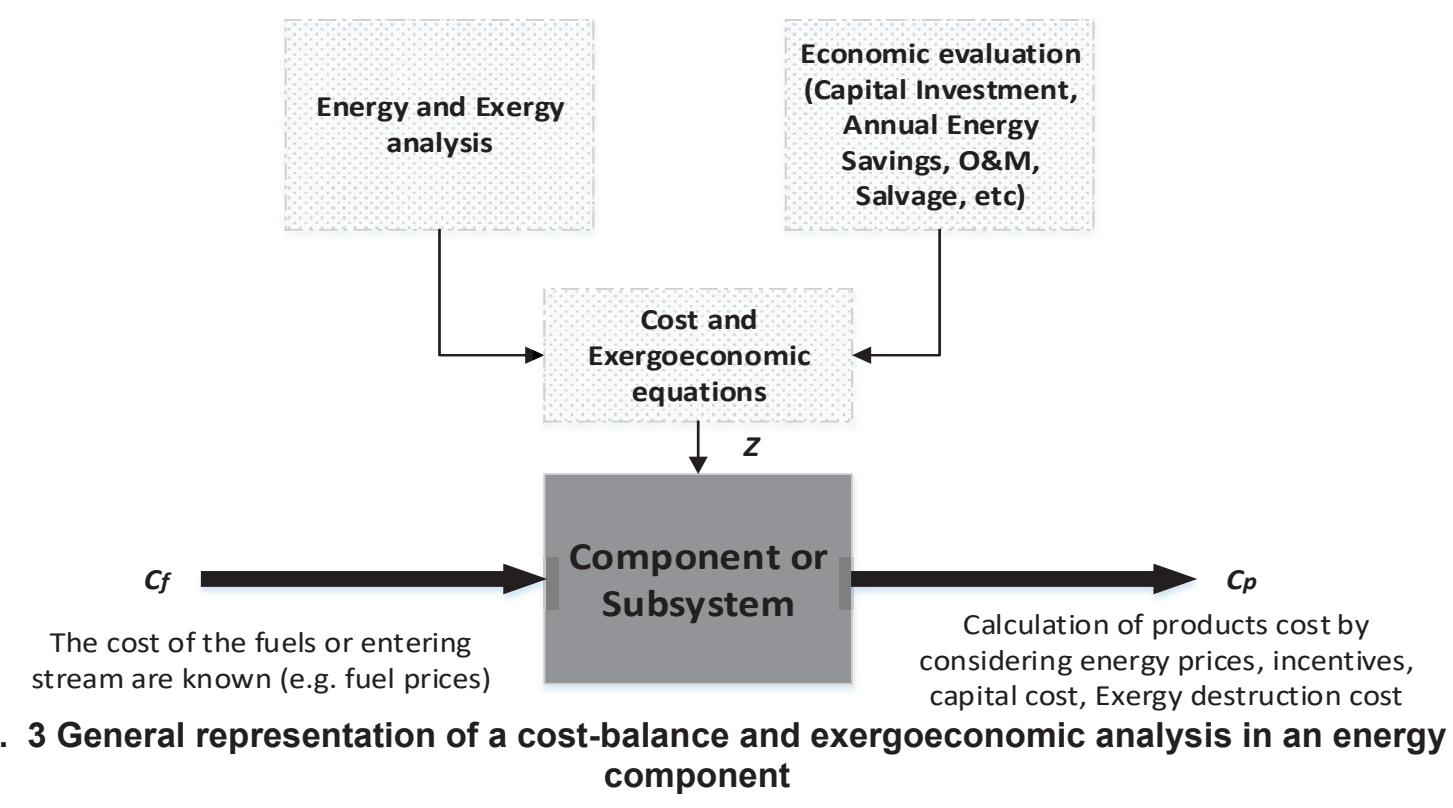

The SPECO method and the 'LowEx' building approach has been previously applied by Yücer and Hepbasli [23] and Baldvinsson and Nakata [65], locating the product cost formation for the heating stream throughout the energy supply chain. However, in this research our model is able to perform exergoeconomic analysis of for four different streams (heating, cooling, DHW, and electric-based equipment), as well as a thermoeconomic life cycle cost of a running building with a specific retrofit project. Fig. 4 presents a schematic block diagram of the subsystems and streams that were analysed in this research.

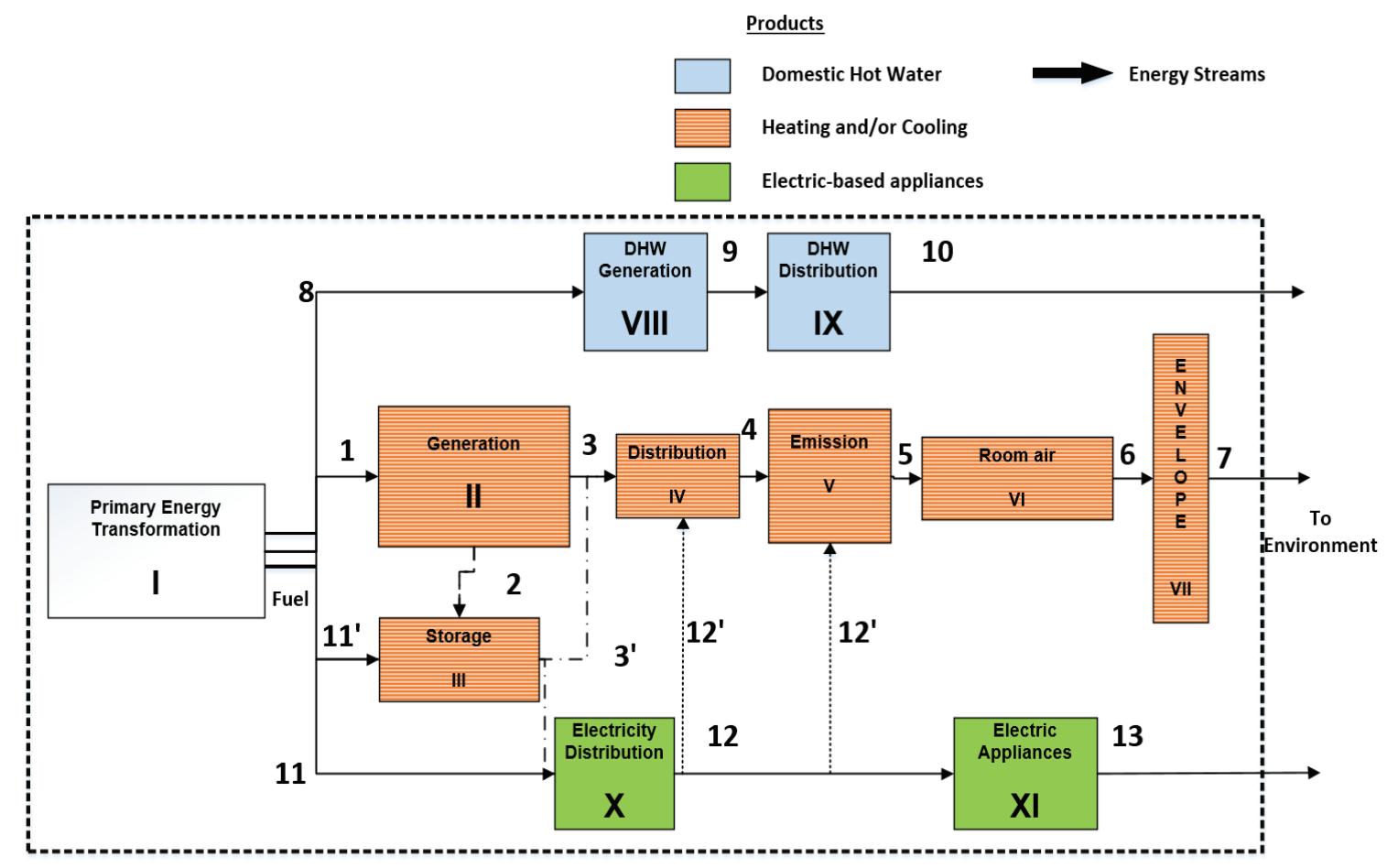

Fig. 4 Schematic diagram of energy supply subsystems and energy streams in a building (HVAC, DHW, and electric appliances) 
The exergy cost of a product $(P)$ can be regarded as the exergy content plus the sum of irreversibilities along the process. As exergy destructions directly affects the cost of the products, whilst being consumed along the process, the product's exergy cost inevitably increases. The value depends on two factors: the amount of destructions and the current price of the entering stream (fuel). The most important cost equations from the SPECO method are summarized below.

First, the general exergy balance can be written as follows:

$\dot{E x_{F, k}}=\dot{E} x_{P, k}+\dot{E x_{D, k}}$

where $\dot{E x_{F, k}}, \dot{E x_{P, k}}$, and $\dot{E x_{D, k}}$ are the fuel exergy, product exergy, and exergy destruction of the component $\mathrm{k}$, respectively.

An exergy cost stream $\dot{C}_{i}$ associated with the corresponding stream $i$ is calculated as follows:

$\dot{C}_{i}=c_{i} E x_{i}$

where $c_{i}$ and $E x_{i}$ are the stream's specific cost and exergy, respectively.

By combining exergy balance and thermoeconomics, we obtain the general cost balance expression. Where the exergy cost balance $\dot{C}_{p, k}$ related to a subsystem is expressed as follows:

$\dot{C}_{p, k}=\dot{C}_{D, k}+\dot{Z}_{k}$

Where $\dot{C}_{D, k}$ and $\dot{Z}_{k}$ is the exergy destruction cost and sum of capital investment rate for the component $k$, respectively. In addition, the exergy destruction cost of a component $\dot{C}_{D, k}$ is defined as:

$\dot{C}_{D, k}=c_{f, K} \dot{E} x_{D, k}$

where $c_{f, K}$ and $\dot{E} x_{D, k}$ are the fuel cost and exergy destructions for the component $k$, respectively. To obtain building total exergy destruction cost, a sum of all subsystems components has to be done:

$\dot{C}_{D, s y s}=\sum_{k=0}^{n}\left(c_{f, K} \dot{E} x_{D, k}\right)$

To account for the component capital investment $Z_{k}$, we converted it into an hourly rate, dependant on the project's lifetime. This is done by using Eq. 12: 


$$
\dot{Z}_{k}=\frac{P W \cdot C R F}{\tau}
$$

where $P W$ is the present factor of the retrofit measure, $C R F$ is the capital recovery, and $\tau$ is the equipment annual working hours. PW and CRF are obtained by using Eq. 13 and 14 respectively:

$$
\begin{aligned}
& P W=T C I-\frac{S V_{N}}{(1+i)^{N}} \\
& C R F=\frac{i(1+i)^{n}}{(1+i)^{n}-1}
\end{aligned}
$$

Table 5 shows the exergy and exergoeconomic balance used in the model. By solving these equations, the cost of energy streams and the economic impact by subsystem are obtained. Outputs are presented as average cost per unit ( $£ / \mathrm{kWh})$.

Table 5 Exergoeconomic balance for subsystems and streams

\begin{tabular}{cclll}
\hline No. & Subsystem & \multicolumn{1}{c}{ Exergy Fuel } & Exergy Product & \multicolumn{1}{c}{$\begin{array}{c}\text { Exergoeconomic } \\
\text { balance }\end{array}$} \\
\hline I & $\begin{array}{c}\text { Primary Energy } \\
\text { Transformation }\end{array}$ & $F_{I}=$ (Raw energy sources) & $P_{I}=\dot{E} \dot{x}_{1}$ & $\dot{C}_{0}+\dot{Z}_{I}=\dot{C}_{1}$ \\
II & Generation & $F_{I I}=E \dot{x}_{1}$ & $P_{I I}=E \dot{x}_{2}+E \dot{x}_{3}$ & $\dot{C}_{1}+\dot{Z}_{I I}=\dot{C}_{2}$ \\
III & Storage & $F_{I I I}=E \dot{x}_{2}+E \dot{x}_{11 \prime}$ & $P_{I I I}=E \dot{x}_{3 \prime}$ & $\dot{C}_{2}+\dot{C}_{11}+\dot{Z}_{I I I}=\dot{C}_{3}$ \\
IV & Distribution & $F_{I V}=E \dot{x}_{3}+E \dot{x}_{3 \prime}+E \dot{x}_{12 \prime}$ & $P_{I V}=E \dot{x}_{4}$ & $\dot{C}_{3}+\dot{C}_{12}+\dot{Z}_{I V}=\dot{C}_{4}$ \\
V & Emission & $F_{V}=E \dot{x}_{4}+E \dot{x}_{12 \prime}$ & $P_{V}=E \dot{x}_{5}$ & $\dot{C}_{4}+\dot{C}_{12}+\dot{Z}_{V}=\dot{C}_{5}$ \\
VI & Room Air & $F_{V I}=E \dot{x}_{5}$ & $P_{V I}=E \dot{x}_{6}$ & $\dot{C}_{5}+\dot{Z}_{V I}=\dot{C}_{6}$ \\
VII & Envelope & $F_{V I I}=E \dot{x}_{6}$ & $P_{V I I}=E \dot{x}_{7}$ & $\dot{C}_{6}+\dot{Z}_{V I I}=\dot{C}_{7}$ \\
VIII & DHW Generation & $F_{V I I I}=E \dot{x}_{8}$ & $P_{V I I I}=E \dot{x}_{9}$ & $\dot{C}_{8}+\dot{Z}_{V I I I}=\dot{C}_{9}$ \\
IX & DHW Distribution & $F_{I X}=E \dot{x}_{9}$ & $P_{I X}=E \dot{x}_{10}$ & $\dot{C}_{9}+\dot{Z}_{I X}=\dot{C}_{10}$ \\
$\mathrm{X}$ & Electricity & $F_{X}=E \dot{x}_{11}+E x_{3 \prime}$ & $P_{x}=E \dot{x}_{12}$ & $\dot{C}_{11}+\dot{C}_{3^{\prime}}+\dot{Z}_{X}=\dot{C}_{12}$ \\
XI & Electric Appliances & $F_{X I}=E \dot{x}_{12}$ & $P_{X I}=E \dot{x}_{13}$ & $\dot{C}_{12}+\dot{Z}_{X I}=\dot{C}_{13}$ \\
\hline
\end{tabular}

In addition, two additional performance indicators were calculated: the relative cost difference and the exergoeconomic factor. These are especially useful for comparison of different BER design options. The relative cost difference $r_{k}$ is calculated as follows:

$$
r_{k}=\frac{c_{P . k}-c_{F, k}}{c_{F, k}}
$$


Where $c_{P . k}$ is the average cost of the product and $c_{F, k}$ is the average cost of fuel at the component $k$. The indicator shows the increase in product price compared to the price of the entering stream (fuel).

The exergoeconomic factor $f_{k}$ shows the ratio of the component capital cost to the component's 'total cost'. The 'total cost' consists on capital cost, O\&M cost, and exergy destructions cost. This is obtained as follows:

$f_{k}=\frac{\dot{Z}_{k}}{\dot{Z}_{k}+c_{F, k}\left(\dot{E} x_{D, k}\right)}$

The outputs highlight the principal source of a component's expenditure. If the value is close to one it means that component's capital cost is the main origin of expenditure, while if the value is close to zero it means that exergy destruction cost it is the main source of expenditure. This is useful, as it allows the practitioner to choose between reducing the necessary capital investment for the component/system or to focus on increasing component exergy efficiency.

As typical economic cost-benefit assessment does not consider exergy destructions, and with the aim of integrating exergoeconomic evaluation in typical economic analysis for buildings, the SPECO method was extended in this study through the inclusion of a new indicator: the exergoeconomic cost-benefit index Exec $_{C B}$, calculated as follows:

$\operatorname{Exec}_{C B}=\dot{C}_{D, s y s}+\dot{Z}_{s y s}-\dot{R}$

where $\dot{C}_{D, s y s}$ is the building total exergy destruction cost rate (eq. 15), $\dot{Z}_{s y s}$ is the annual capital cost rate for the retrofit measure (eq. 16), and $\dot{R}$ is the annual revenue rate. The revenue is calculated based on the project's lifetime and considering the present value of money. The outputs are given in $£ / h$. For BER analysis, a benchmark value is first calculated for the baseline building. For the base case, this indicator only includes exergy destruction costs $\dot{C}_{D, s y s}$ as no retrofit measure $\left(\dot{Z}_{\text {sys }}\right)$ has been applied and consequently no revenue $(\dot{R})$ has been generated. After the retrofit analysis is performed, if the retrofitted building presents a Exec $_{C B}$ lower than the baseline $\dot{C}_{D, \text { sys }}$, the design represents both a cost-effective solution and an improvement in exergy performance.

\subsection{Other non-thermodynamic parameters}

To account for occupant thermal comfort the "Thermal Comfort Not Comfortable Time" outputs calculated directly by EnergyPlus were used. This value is based on the ASHRAE 55-2004 
method [66], and provides the number of hours per year that internal conditions are not in the summer or winter clothes region. This method considers the combination of humidity ratio and operative temperature with personal factors (physical, adaptive, and organismic) that will produce acceptable conditions to $80 \%$ or more occupants within the building.

For the analysis of the carbon footprint ( $\mathrm{CO}_{2}$ emissions), only emissions due to energy use during building's lifetime operation were considered, thus technology embodied emissions (including embodied exergy) were neglected in this research. The emission factors for different fuels used are shown in Table 6.

\begin{tabular}{ll}
\multicolumn{2}{l}{ Table 6 Emission factors for different energy sources } \\
\hline Energy source & $\mathbf{k g C O 2 e / k W h}$ \\
\hline Natural gas (Boiler, CHP, District) & 0.212 \\
Electricity (grid) & 0.522 \\
Fuel oil & 0.313 \\
Biomass (Wood pellets) & 0.039 \\
PV/T electricity and solar thermal & 0.075 \\
Wind electricity & 0.038
\end{tabular}

For future years, a moderate future electricity linear decarbonisation was considered, going from the current value of 0.522 to a value of $0.20 \mathrm{kgCO}_{2} \mathrm{e} / \mathrm{kWh}$ by the end of the analysis period (50 years). The factors for the other fuel types were assumed as constant.

\section{Case Studies and baseline values}

\subsection{Building energy model calibration}

The case studies are based on two typical non-domestic buildings located in the UK (an office and a primary school). The sources for the archetype development as well as main characteristics have been presented in previous research [37]. The buildings were assumed to be built before first building energy regulations were implemented prior to 1965 . The HVAC systems were selected to be representative of those installed in these building types and ages [67] and the London-Gatwick weather file was used as the reference environment. 
A comprehensive sensitivity and uncertainty analysis was performed to calibrate the building models to national mean values for electricity and gas use in non-domestic buildings [68-70]. Two-hundred different models were created by sampling eight parameters that have significant impact on energy utilisation [71]: 1) lighting power density, 2) equipment power density, 3) building orientation, 4) envelope thermal conductivity, 5) air tightness, 6) occupant density, 7) set point controls, and 8) HVAC system efficiency. The calibration procedure was implemented through the use of the Latin hypercube sampling method combined with Monte Carlo analysis within SimLab 2.2 [72] software environment. All the simulated buildings (in blue) and the selected baseline model (in red) for both archetypes are illustrated in Fig. 5. The baseline building characteristics for both models are presented in Table 7.
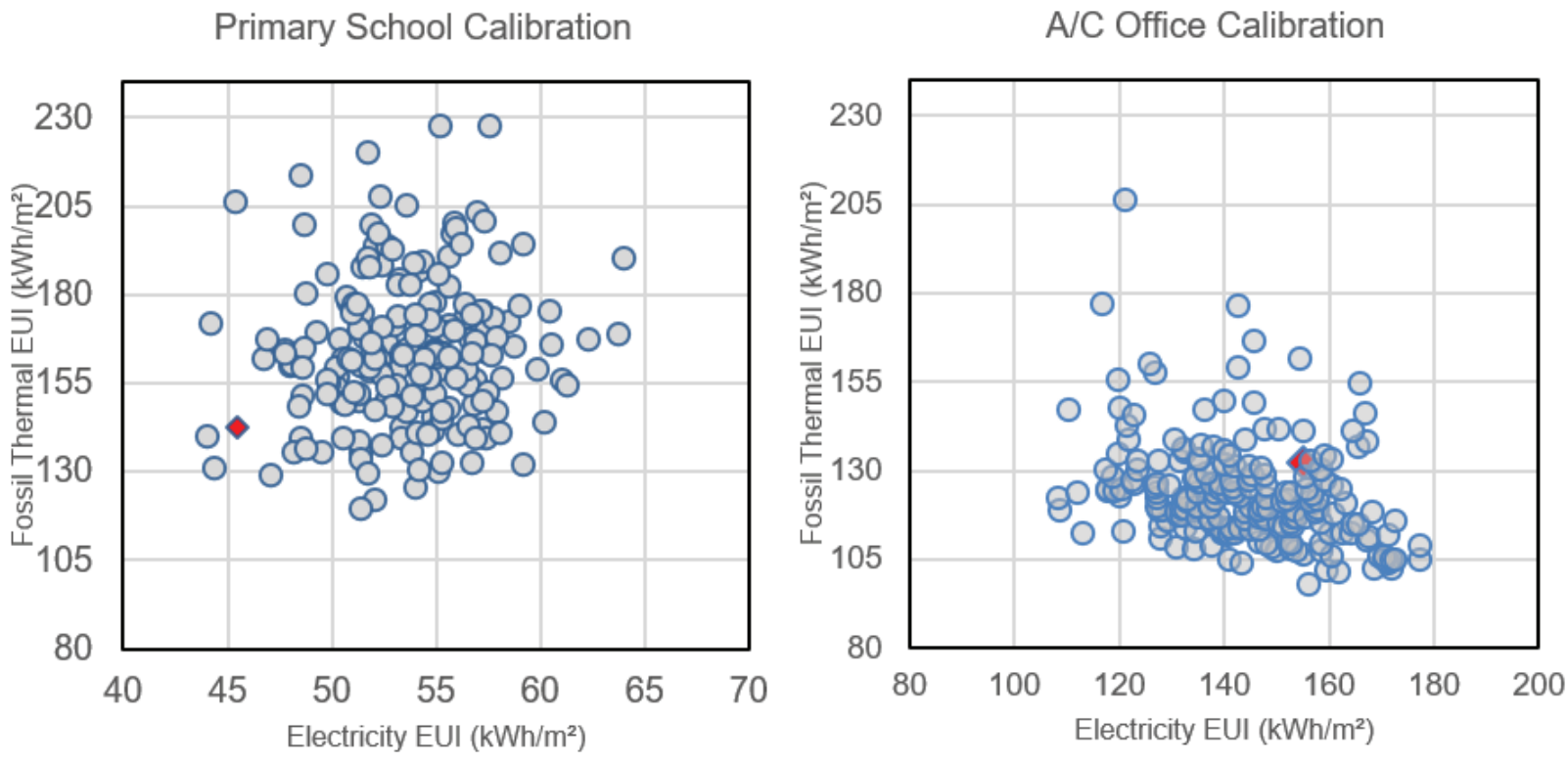

Fig. 5 Simulation cases from Latin Hypercube Sampling 
Table 7 Case studies baseline characteristics

\begin{tabular}{|c|c|c|}
\hline Baseline characteristics & Primary School & A/C Office \\
\hline Year of construction & 1960s & 1960s \\
\hline Number of floors & 2 & 3 \\
\hline Floor space $\left(m^{2}\right)$ & 1990 & 2590 \\
\hline Orientation ( ${ }^{9}$ & 227 & 31 \\
\hline Air tightness (ach) & 1.0 & 1.0 \\
\hline Exterior Walls & $\begin{array}{c}\text { Cavity Wall-Brick walls } 100 \mathrm{~mm} \\
\text { brick with } 25 \mathrm{~mm} \text { air gap } \\
\left(\mathrm{U} \text {-value }=1.66 \mathrm{~W} / \mathrm{m}^{2} \mathrm{~K}\right)\end{array}$ & $\begin{array}{c}\text { Cavity Wall-Brick walls } 100 \mathrm{~mm} \\
\text { brick with } 25 \mathrm{~mm} \text { air gap } \\
\left(\mathrm{U} \text {-value }=1.61 \mathrm{~W} / \mathrm{m}^{2} \mathrm{~K}\right)\end{array}$ \\
\hline Roof & $\begin{array}{l}\text { 200mm concrete block } \\
\left(\mathrm{U} \text {-value }=3.12 \mathrm{~W} / \mathrm{m}^{2} \mathrm{~K}\right)\end{array}$ & $\begin{array}{l}\text { 200mm concrete block } \\
\left(\mathrm{U} \text {-value }=3.12 \mathrm{~W} / \mathrm{m}^{2} \mathrm{~K}\right)\end{array}$ \\
\hline Ground floor & $\begin{array}{l}150 \mathrm{~mm} \text { concrete block } \\
\left(\mathrm{U} \text {-value }=1.31 \mathrm{~W} / \mathrm{m}^{2} \mathrm{~K}\right)\end{array}$ & $\begin{array}{l}150 \mathrm{~mm} \text { concrete block } \\
\left(\mathrm{U} \text {-value }=1.31 \mathrm{~W} / \mathrm{m}^{2} \mathrm{~K}\right)\end{array}$ \\
\hline Windows & Single-pane clear (5mm thick) & Single-pane clear (5mm thick) \\
\hline Glazing ratio & $28 \%$ & $41 \%$ \\
\hline HVAC System & $\begin{array}{c}515 \mathrm{~kW} \text { Gas-fired boiler } \\
(\eta=82 \%)\end{array}$ & $\begin{array}{c}750 \text { kW Gas-fired boiler } \\
(\eta=70 \%) \\
\text { Air-based Chiller } 272 \mathrm{~kW} \\
(\mathrm{COP}=2.0)\end{array}$ \\
\hline Emission system & $\begin{array}{l}\text { Heating: HT Radiators } 90 / 70^{\circ} \mathrm{C} \\
\text { Cooling: Natural ventilated }\end{array}$ & $\begin{array}{l}\text { Heating: CAV } 80 / 50^{\circ} \mathrm{C} \\
\text { Cooling: CAV } 7 / 12^{\circ} \mathrm{C}\end{array}$ \\
\hline Heating Set Point $\left({ }^{\circ} \mathrm{C}\right)$ & 19.3 & 21.9 \\
\hline Cooling Set Point $\left({ }^{\circ} \mathrm{C}\right)$ & -- & 24.0 \\
\hline Occupancy (people/m²)* & 2.1 & 8.2 \\
\hline Equipment $\left(W / m^{2}\right)^{*}$ & 2.0 & 14.9 \\
\hline Lighting level $\left(W / m^{2}\right)^{*}$ & 12.2 & 21.4 \\
\hline EUI electricity $\left(\mathrm{kWh} / \mathrm{m}^{2}-\mathrm{y}\right)$ & 45.6 & 158.3 \\
\hline EUI gas $\left(k W h / m^{2}-y\right)$ & 142.3 & 130.2 \\
\hline Annual energy bill ( $£ / y)$ & 19449 & 59625 \\
\hline Thermal discomfort (hours) & 1443 & 1413 \\
\hline CO2 emissions (Ton) & 214.8 & 285.6 \\
\hline
\end{tabular}

*Just for main areas. School: Classrooms and Staff offices. A/C Office: Open plan office space

\subsection{Exergetic and exergoeconomic baseline values}

\subsubsection{Exergy destructions per end-use}

To highlight the differences between the building types, the share of destructions per component were analysed (Fig. 6). In the office case, the largest share of irreversibilities occurs in the generation of electricity used for electric-based appliances (51\%), followed by the HVAC generation subsystem (23\%) as a result of burning gas for heating purposes. In the school case, the HVAC generation subsystem presents the largest destruction per end-use (41\%). For both buildings, the HVAC "primary energy transformation" subsystem exergy destructions are rather low, although in the office it represents a larger share due to the use of electricity for cooling process during summer. 


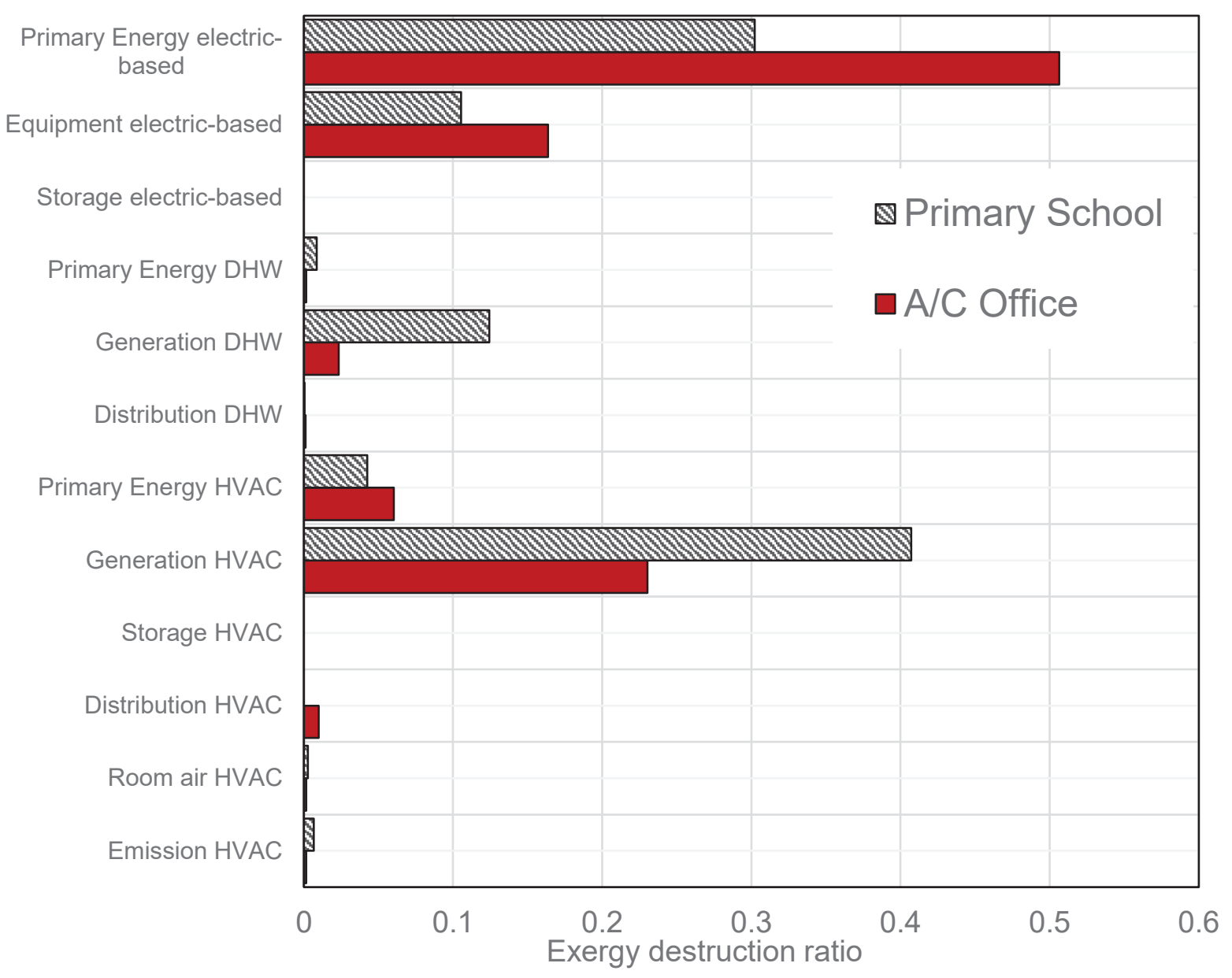

Fig. 6 Exergy destruction ratio of all energy subsystems for both buildings

\subsubsection{Baseline exergoeconomic indicators}

Fig. 7-9 illustrate exergy destruction accumulation compared to the stream cost formation through the HVAC supply chain. Fig 7 shows how the school heating product at the end of the energy supply chain increases from $£ 0.03 / \mathrm{kWh}$ (gas price) to $£ 1.79 £ / \mathrm{kWh}$, with a total relative cost difference $r_{k}$ of 58.66 . The largest increase occurs at the generation (gas boiler) and envelope subsystems. 


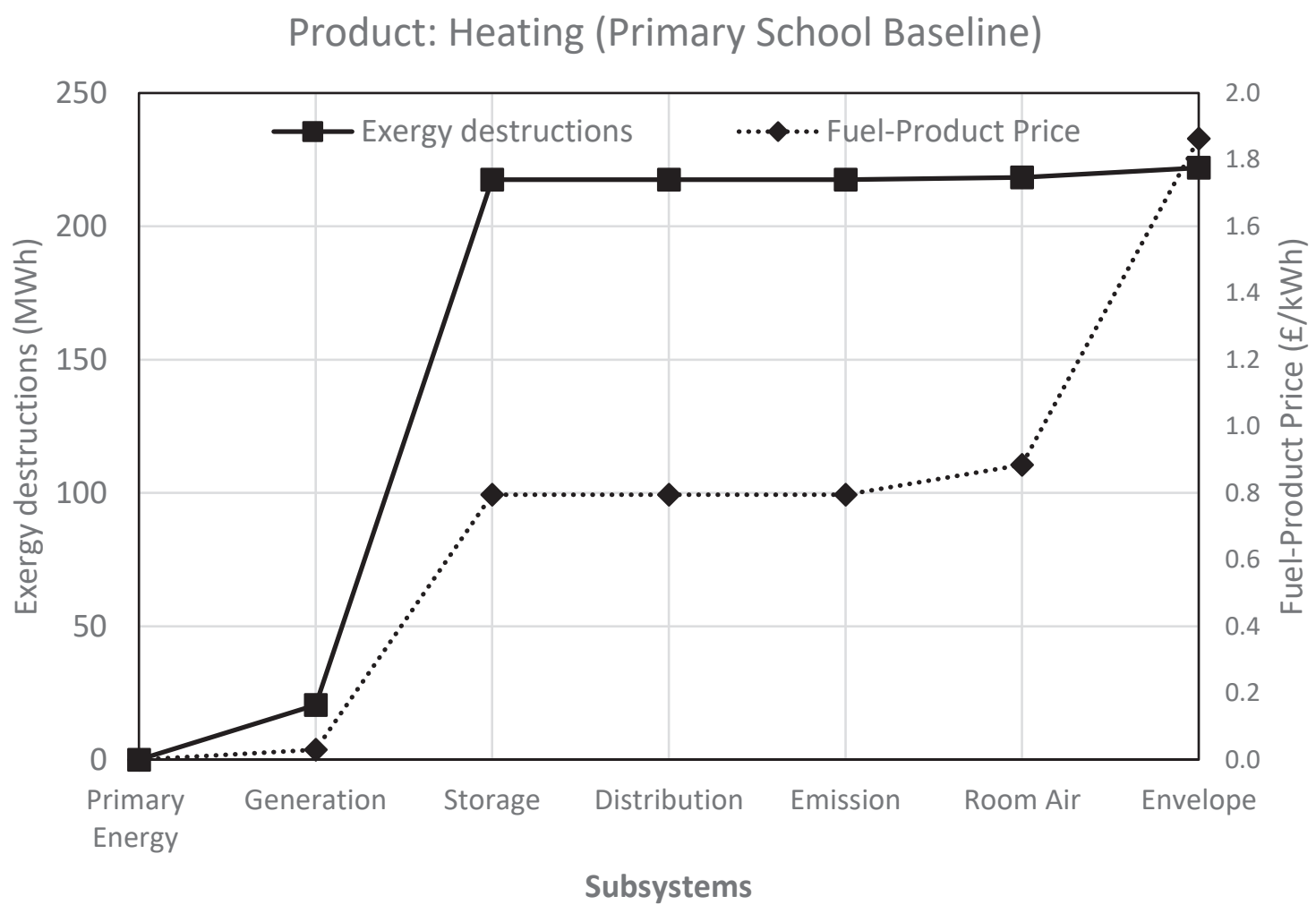

Fig. 7 Exergy destruction accumulation vs product cost formation for heating stream. Primary School

For the office case it is possible to show the streams for the two thermal products: heating and cooling. In Fig. 8, the heating product in the office increased from $£ 0.03 / \mathrm{kWh}$ to $£ 0.45 / \mathrm{kWh}$, having a total relative cost difference $r_{k}$ of 13.9. In this case, the generation and distribution subsystems are areas of concern. For the cooling product (Fig. 9), exergy cost starts at $£ 0.12 / \mathrm{kWh}$ (electricity price) and increases up to $£ 3.10 / \mathrm{kWh}\left(r_{k}=24.9\right)$. Attention has to be put to the generation (low efficient chiller), the distribution, and emission systems, where the biggest cost increases were found. 


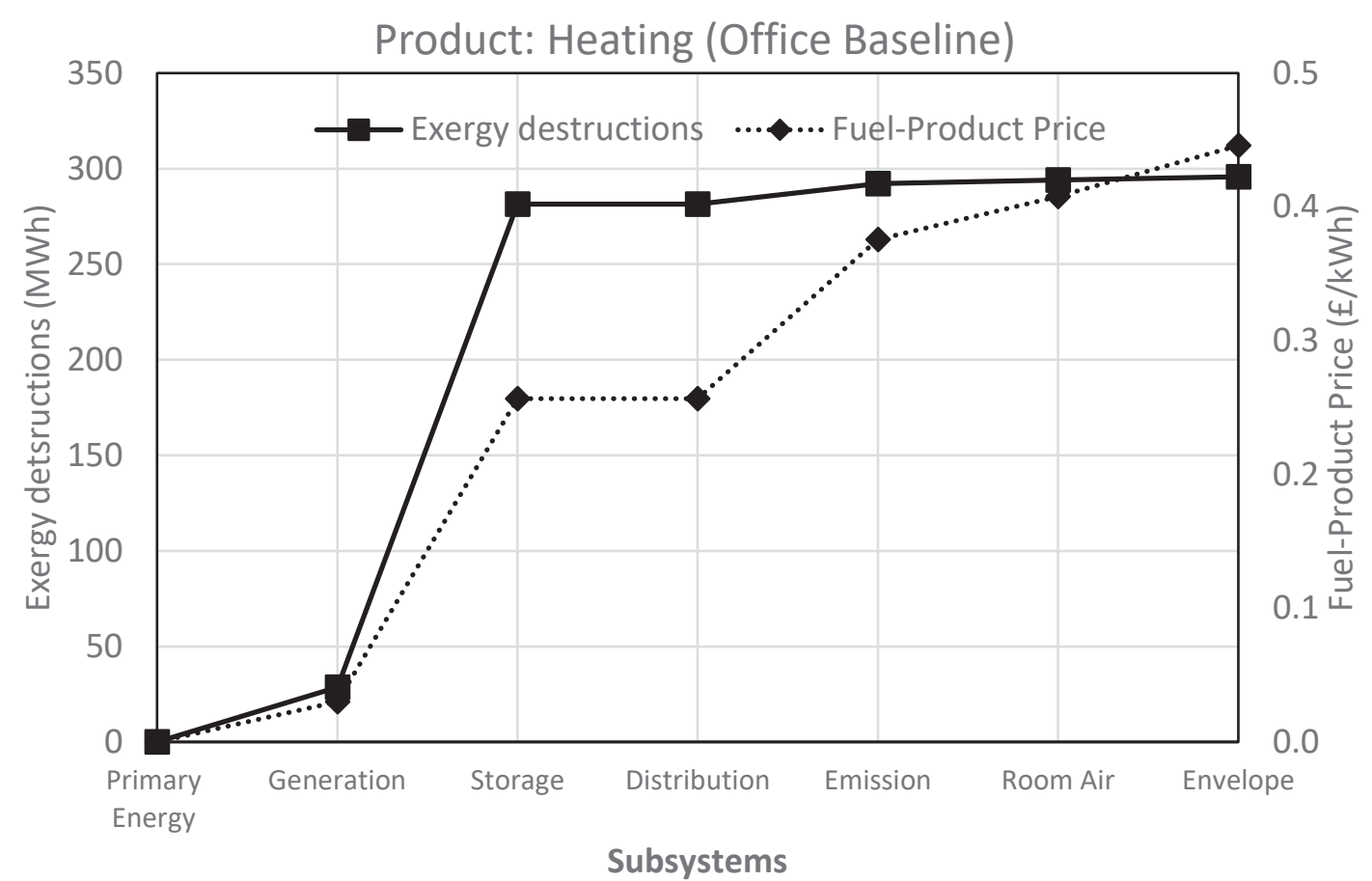

Fig. 8 Exergy destruction accumulation vs product cost formation for heating stream. A/C Office

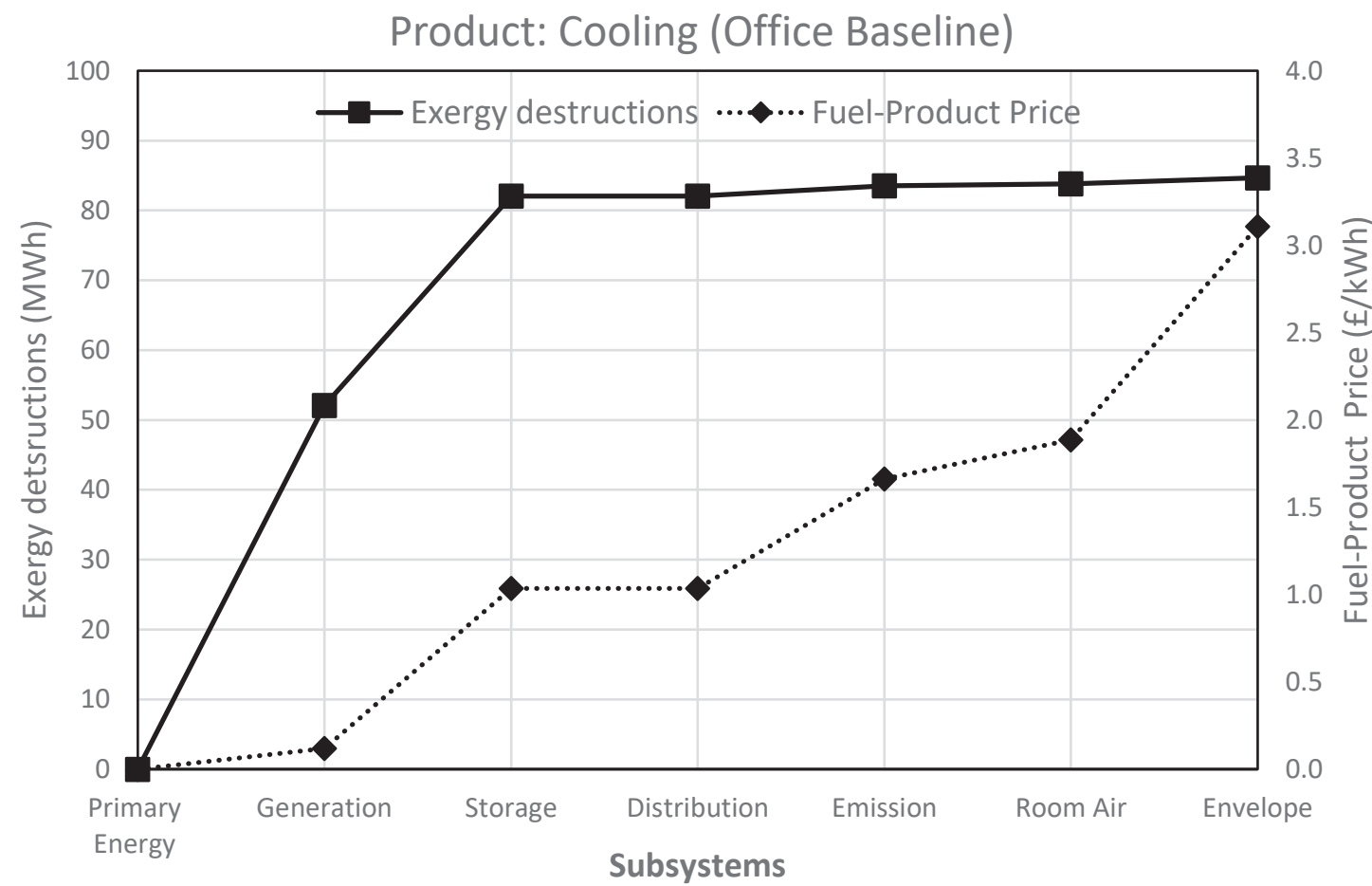

Fig. 9 Exergy destruction accumulation vs product cost formation for cooling stream . A/C Office

In many cases exergy cost for heating and cooling products can differ dramatically, as the exergy cost significantly depends on temperatures. In this sense, cooling processes by working closer to ambient temperature (thus having a small $\Delta T$ ), any exergy destructions are 
highly penalised in exergy/exergoeconomic analyses. Added to this, the conversion efficiency of any subsystem can also have a big impact on the final product price. This fuel-product analysis was done for all streams (heating, cooling, DHW, and electric appliances). Baseline exergoeconomic values for both buildings can be seen in Table 8.

Table 8 Baseline buildings exergoeconomic values

\begin{tabular}{lll}
\hline Baseline characteristics & Primary School & Office \\
\hline Exergy input (fuel) (MWh) & 533.0 & 1440.8 \\
Exergy demand (product) (MWh) & 43.5 & 212.6 \\
Exergy destructions (MWh) & 489.4 & 1228.2 \\
Exergy efficiency HVAC & $1.5 \%$ & $5.1 \%$ \\
Exergy efficiency DHW & $6.2 \%$ & $8.7 \%$ \\
Exergy efficiency Electric equip. & $15.1 \%$ & $18.9 \%$ \\
Exergy efficiency Building & $8.2 \%$ & $14.8 \%$ \\
Exergy cost fuel-prod HEAT (£/kWh) $\left\{r_{k}\right\}$ & $0.03-1.86\{61.11\}$ & $0.03-0.45\{13.86\}$ \\
Exergy cost fuel-prod COLD (£/kWh) $\left\{r_{k}\right\}$ & $----\{---\}$ & $0.12-3.11\{24.89\}$ \\
Exergy cost fuel-prod DHW (£/kWh) $\left\{r_{k}\right\}$ & $0.03-0.44\{13.72\}$ & $0.03-0.55\{17.49\}$ \\
Exergy cost fuel-prod Elec (£/kWh) $\left\{r_{k}\right\}$ & $0.12-0.31\{1.60\}$ & $0.12-0.25\{1.07\}$ \\
$\begin{array}{l}\text { D Exergy destructions cost }(£ / h)[e n e r g y \\
\text { bill £; \% D from energy bill\} }\end{array}$ & $2.72\{18432.6 ; 94.7 \%\}$ & $6.54\{44,661.0 ; 74.9 \%\}$ \\
$Z$ Z (£/h) & 0 & 0 \\
Exergoeconomic factor $f_{k}(\%)$ & 1 & 1 \\
Exergoeconomic cost-benefit $(£ / h)$ & 2.89 & 6.54 \\
\hline
\end{tabular}

As discussed in section 2.4.3, the expanded exergoeconomic cost-benefit indicator for the baseline cases is the same as the building cost exergy destructions $\left(\operatorname{Exec}_{C B}=\dot{C}_{D, \text { sys }}\right)$ as no retrofit strategy has been implemented. For the school, this has a value of $£ 2.89 / \mathrm{h}$ and for the office is $£ 6.54 / \mathrm{h}$. In the case of the school, exergy destructions costs represent around $95 \%$ of the annual energy expenditure, while in the office is close to $75 \%$. Fig. 10 shows a detailed evaluation of exergoeconomic cost by locating the destruction cost share per product. 


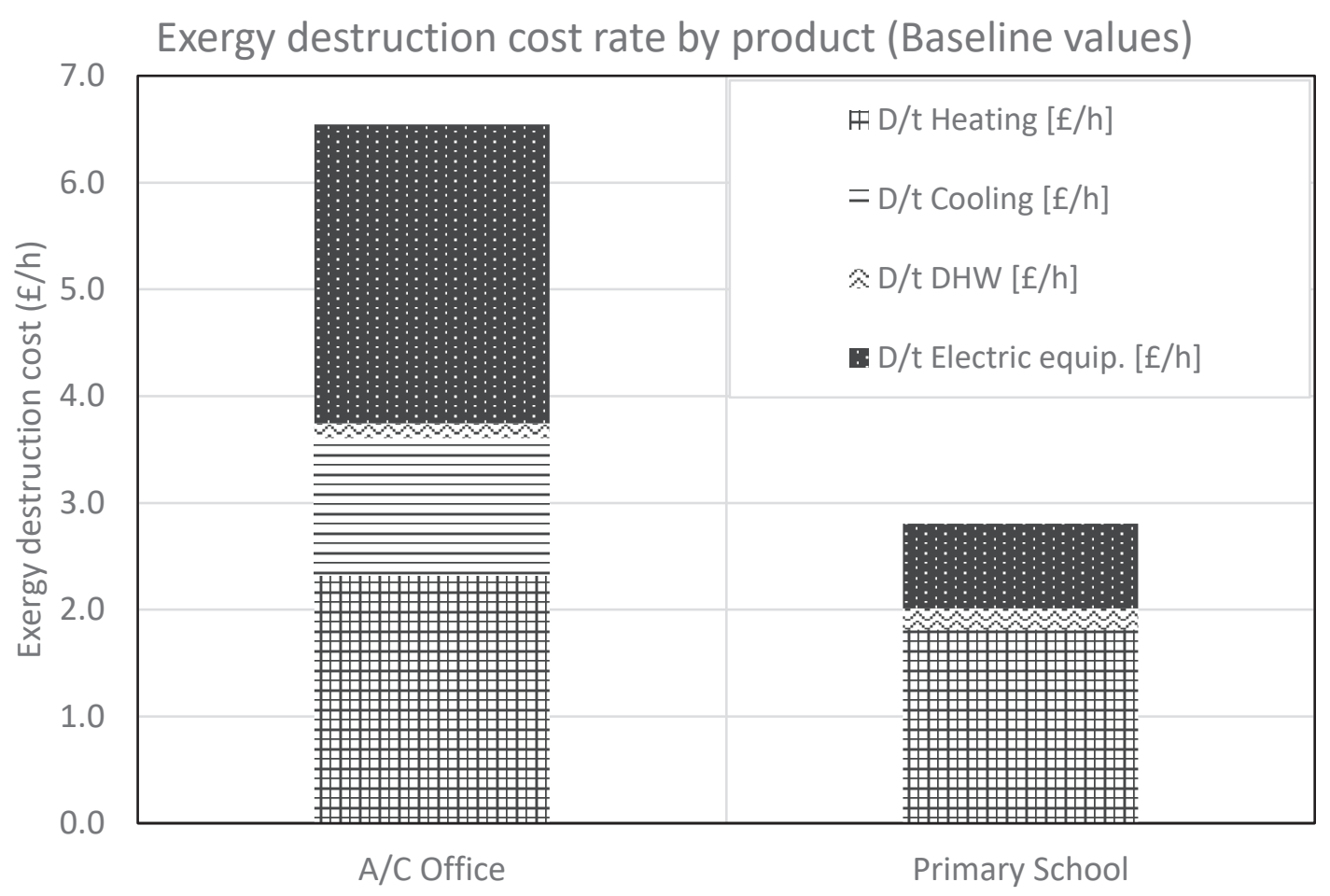

Fig. 10 Exergy destruction cost rate per product type (Baseline)

By considering a trade-off between exergy destruction cost, project capital cost, and annual revenue, a good exergoeconomic-based BER design will present lower values of $\operatorname{Exec}_{C B}$ than the baseline $\dot{C}_{D, s y s}$ value.

\section{Results and Discussions}

Both $\operatorname{Exec}_{C B}$ and thermal comfort conditions indicators were used to explore the best retrofit solutions for the two case studies. In some cases, capital investment and NPV were also considered to inform whether the retrofit measure would be used for a further combined strategy.

4.1 First level: By individual measures

To illustrate the results of a series of BERs, the first level analysis is presented in two parts: one for HVAC systems exclusively and a separate analysis for the rest of measures. 


\subsubsection{HVAC retrofits}

\section{Office}

The best exergy performance was obtained through the use of H32: boiler plus a MVHR system, which achieved an HVAC exergy efficiency of $19.3 \%$. The final heating product cost was $0.14 £ / \mathrm{kWh}$, while the cooling product was $0.25 £ / \mathrm{kWh}$.. The system also achieved the best exergoeconomic performance with an $\operatorname{Exec}_{C B}$ of $£ 3.23 / \mathrm{h}$ (well below the $£ 6.54 / \mathrm{h}$ of the baseline case). The total capital cost for the system was $£ 66,693$ with a DPB of 6.4 years. In addition, designs based on GSHP present the lowest exergy destructions and primary exergy input. The GSHP with underfloor heating $(\mathrm{H} 21)$ also achieved a good exergoeconomic performance with an $\operatorname{Exec}_{C B}$ of $£ 5.42 / \mathrm{h}$, but requiring a much higher capital investment at $£ 409,564$ providing a DPB of 34.9 years.

H24: PV/T system presented the highest NPV due to the additional income from both government incentives schemes for the generation of renewable electricity and hot water. The main drawback associated with this design is the high capital investment required $(£ 873,200)$. However, exergoeconomic analysis highly penalises this design due to the fact of high capital costs, resulting in a $\operatorname{Exec}_{C B}$ of $£ 11.30 / \mathrm{h}$. In terms of thermal comfort, high exergy systems (condensing gas and biomass boilers) with underfloor heating ( $\mathrm{H} 26, \mathrm{H} 29$ respectively) provided the best performance. Fig. 11 shows the results for all the analysed HVAC systems, displaying the best solutions in the Pareto front. All the systems located inside the dotted square represent an improvement in both the exergoeconomic cost-benefit and occupant thermal comfort indicators.

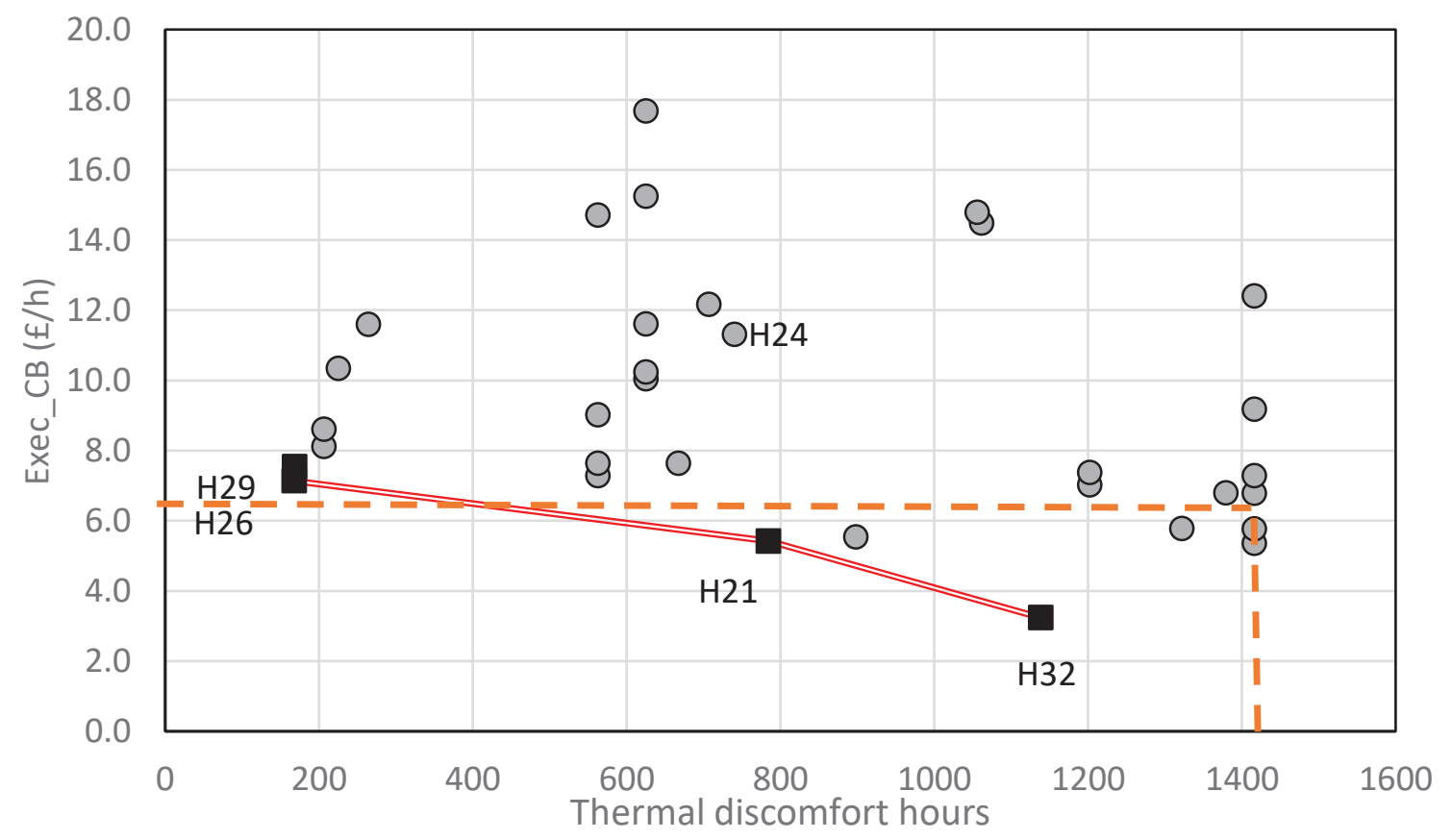

Fig. $11 \mathrm{~A} / \mathrm{C}$ Office: HVAC systems $\operatorname{Exec}_{\mathrm{CB}}$ performance against thermal discomfort 


\section{Primary School}

For the school case, H32: condensing gas boiler + CAV + MVHR and H16: district heating + underfloor system presented the best thermodynamic performance with exergy destructions reduction of up to $80 \%$, however both failed to provide major thermal comfort improvements. The final heating product cost for $\mathrm{H} 32$ and $\mathrm{H} 16$ was $£ 0.26 / \mathrm{kWh}$ and $£ 0.65 / \mathrm{kWh}$, representing an improvement from the base case $(£ 1.89 / \mathrm{h})$. H32 also achieved the best exergoeconomic performance with an $\operatorname{Exec}_{C B}$ of $£ 0.44 / \mathrm{h}$ (compared to the $£ 2.89 / \mathrm{h}$ for the baseline case). The total capital cost for the system was $£ 72,692$ with a DPB of 10.7 years.

As a product of the RHI government incentive, the system with the highest NPV and lowest DPB is H31: micro-CHP system. However, the amount of electricity generated by the CHP that is used exclusively for heating purposes combined with its high capital cost has been penalised by exergoeconomic analysis, achieving an $\operatorname{Exec}_{C B}$ of $£ 6.17 / \mathrm{h}$. Systems where incentives help to achieve low payback periods such as GSHP or waste-heat district systems can achieve better exergoeconomic results by using energy sources with lower energy quality levels. For thermal comfort performance, high exergy systems with large heated areas (wall heating) provided the best performance, but require larger investment costs for the emission systems. Fig. 12 shows the results for all the analysed HVAC systems, identifying five solutions in the Pareto front.

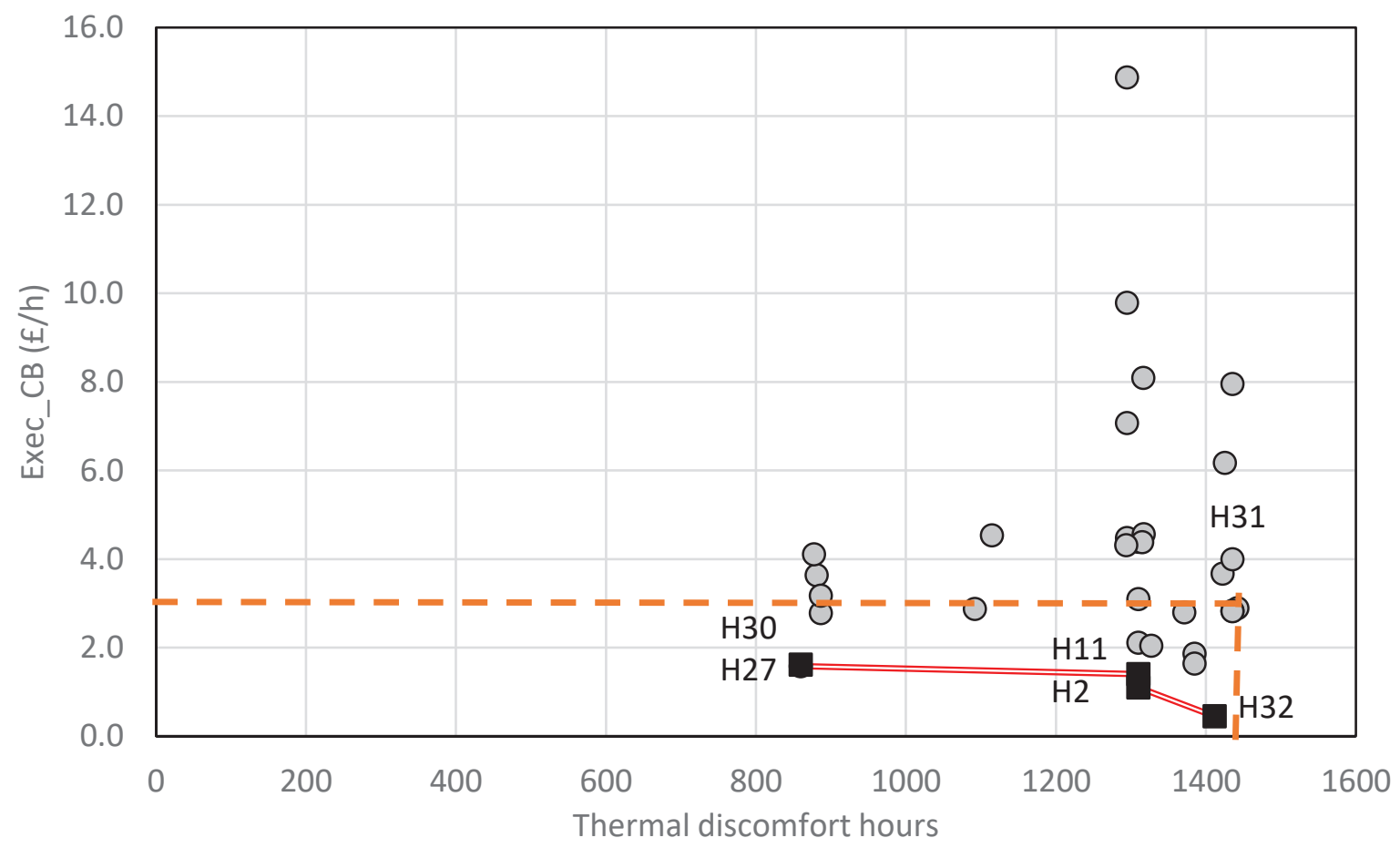

Fig. 12 Primary School: HVAC systems Exec $_{\mathrm{CB}}$ performance against thermal discomfort 


\subsubsection{Non-HVAC retrofits}

Non-HVAC solutions did not achieve any significant system exergy efficiency improvement, but could reduce total exergy destructions by lowering the building energy demand. The rest of the solutions have been differentiated into passive measures (insulation, glazing, sealing, and set-points) and active measures (lighting and renewables).

\section{Office}

For passive measures, insulation technologies such as corkboard (I6) and polyurethane (I1) achieved energy savings of $10 \%$ and reduced exergy destructions by $6 \%$. Economically, the best performer was $0.03 \mathrm{~m}$ of expanded polystyrene, with a capital cost of $£ 14,348.7$, a DPB of 11.6 years, and a $\operatorname{Exec}_{C B}$ of $£ 5.79 / \mathrm{h}$. The envelope $\mathrm{U}$-values $\left(\mathrm{W} / \mathrm{m}^{2}-\mathrm{K}\right)$ achieved for this solution were: 0.38 for the wall, 0.43 for the roof and 0.25 for the ground. Triple glazing systems (air, argon, and krypton) achieved the highest energy savings among passive measures. However, economically none of the glazing systems reached a positive NPV during the project's lifetime (50 years) because of high capital investment cost. On the other hand, a hypothetical reduction of the infiltration rate achieved better economic and exergoeconomic results. An improvement of $60 \%$ of the uncontrolled infiltration achieved the highest NPV and an $\operatorname{Exec}_{C B}$ of $£ 4.95 / \mathrm{h}$. It also achieved energy savings of $18 \%$ and exergy destructions reduction of $11 \%$; however, it improved thermal comfort by just $1.5 \%$. Moreover, changing setpoints it is always a trade-of between obtaining better thermal comfort or extra energy savings. Set-points of $22^{\circ} \mathrm{C}$ for heating, and $24^{\circ} \mathrm{C}$ for cooling provide the best comfort performance but did not produce any significant exergoeconomic change, both measures having an $\operatorname{Exec}_{C B}$ of $£ 6.54 / h$.

For the active measures, L3: LED-based lighting achieved the maximum minimisation of exergy destructions (15\%) and the best $\operatorname{Exec}_{C B}$ indicator $(£ 4.95 / \mathrm{h})$. This involved a capital investment of $£ 177,343.8$, resulting in a DPB of 23.7 years. For renewable systems, the only technology that achieved a positive NPV value and an improvement in $\operatorname{Exec}_{C B}(£ 6.19 / \mathrm{h})$ was R4: $20 \mathrm{~kW}$ wind turbine. Irreversibilities reductions were minimal as electricity were being used for the same end-use processes, where just a slight decrease can be seen at the 'Primary Energy Transformation' subsystem due to the lower fossil fuel utilisation for generation of electricity.

Fig. 13 shows the results for all the non-HVAC measures applied to the office archetype, locating those technologies that have better exergoeconomic and thermal comfort 
performance. As individual measures and for the exclusive case of this office archetype, it is clear that minimising infiltration rate has the biggest impact on both indicators.

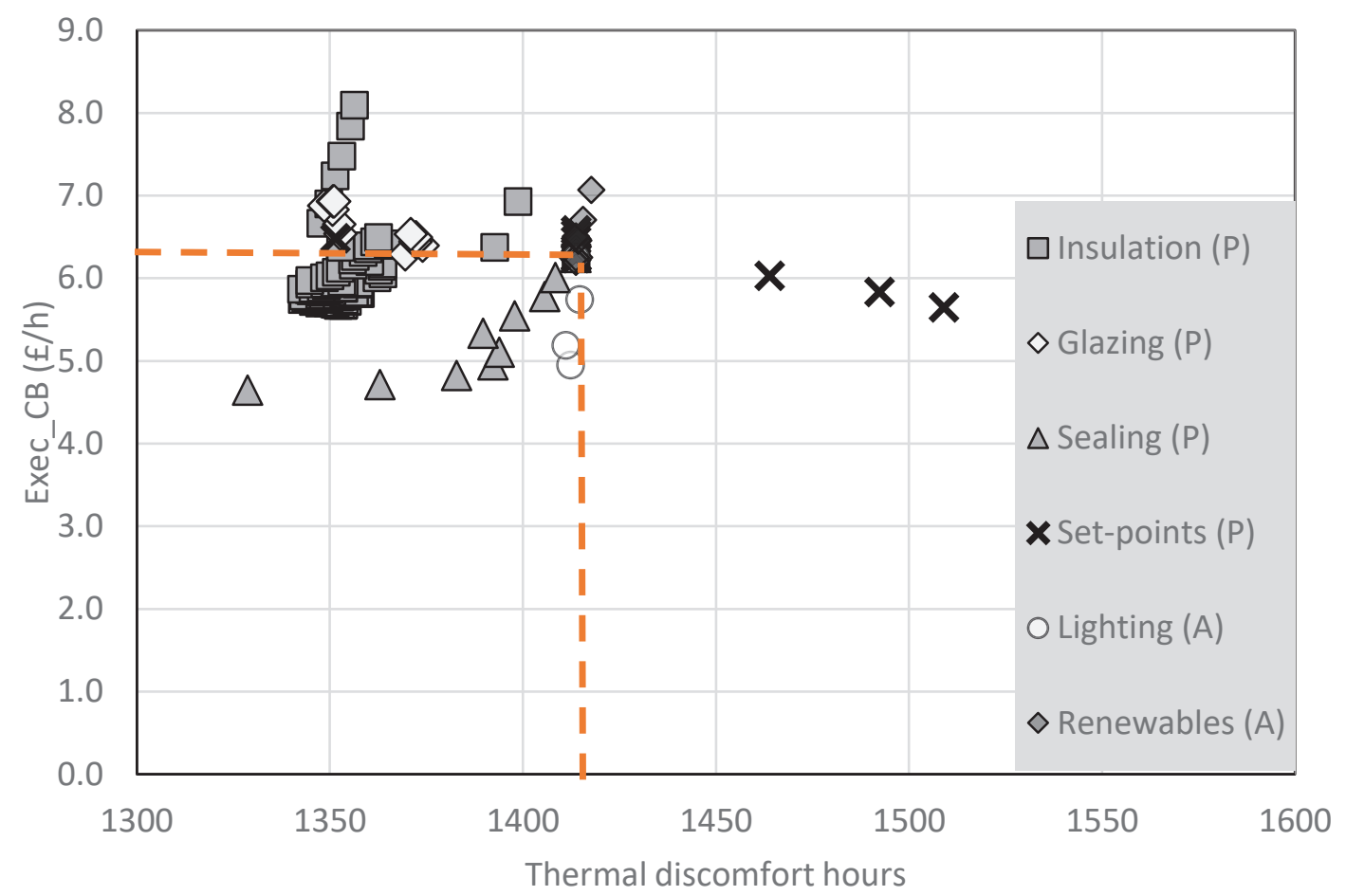

Fig. 13 A/C Office: All BERs (no HVAC) Exec_CB performance against thermal discomfort

\section{School}

For the school case, almost all insulation measures presented an improvement in the analysed indicators. Glass fibre with a thickness of $0.085 \mathrm{~m}$ produced the best overall performance, achieving a DBP of 13 years with an investment of $£ 20,105$, along the lowest $\operatorname{Exec}_{C B}$ among insulation measures with a value of $£ 2.24 / \mathrm{h}$. The $U$-values $\left(\mathrm{W} / \mathrm{m}^{2}-\mathrm{K}\right)$ for this measure were 0.33 for the wall, 0.37 for the roof and 0.32 for the ground. As in the case of the office, glazing systems failed to provide any considerable energy savings and also performed poorly in terms of economic indicators where seasonal occupancy does not justify individual installation. For airtightness measures, an improvement of $70 \%$ in infiltration rates produced the best $\operatorname{Exec}_{C B}$ with a value of $£ 2.53 / \mathrm{h}$, while improving thermal comfort by $4 \%$. Low setpoints $\left(18^{\circ} \mathrm{C}\right)$ achieved good exergoeconomic performance $\left(\operatorname{Exec}_{C B}=£ 2.31 / \mathrm{h}\right)$ but with a comfort decrease of $1 \%$. On the other hand, a setpoint of $22^{\circ} \mathrm{C}$ has poor exergoeconomic performance $\left(\operatorname{Exec}_{C B}=£ 3.70 / \mathrm{h}\right)$, but increases thermal comfort by $21 \%$.

Among lighting technologies, LED system achieved the best energy results; however, exergoeconomic indicators did not significantly improve compared to the baseline. For 
renewable measures, exergy destructions were not minimised due to the fact that electricity was still being used for the same end-uses. Analysing the NPV, only the R4: $20 \mathrm{~kW}$ turbine achieved a positive value and an $\operatorname{Exec}_{C B}$ of $£ 2.70 / \mathrm{h}$. The installation of stand-alone PV panels without the improvement on other areas provide poor exergoeconomic results. Fig. 14 shows the results for all the non-HVAC measures applied to the school archetype, locating those that have better exergoeconomic and thermal comfort performance compared to the baseline case.

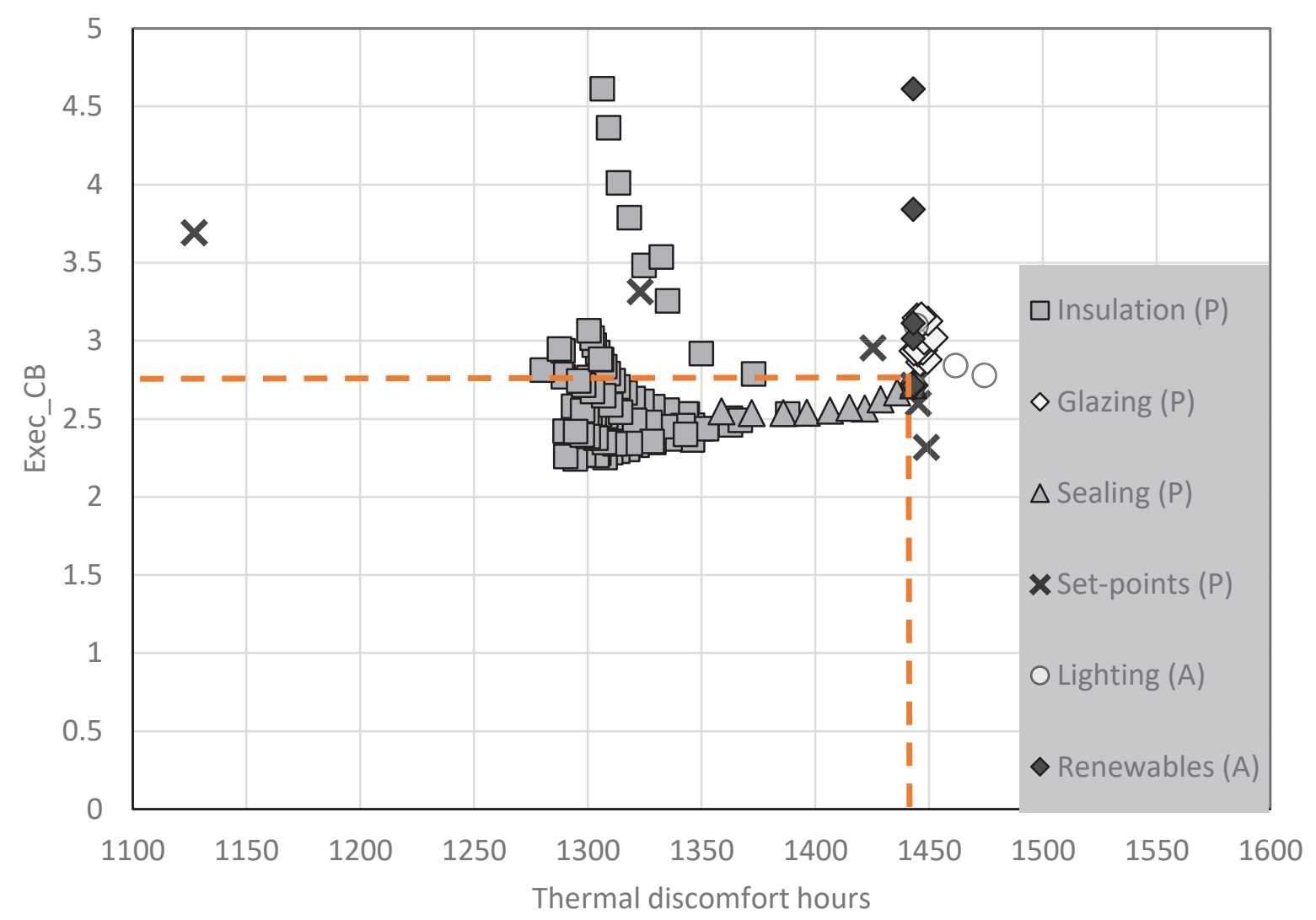

Fig. 14 Primary School: All BERs (no HVAC) Exec_CB performance against thermal discomfort

\subsection{Further improvement: Combined Measures ( $2^{\text {nd }}$ level)}

Since the benefit of a combined retrofit scenario is not the sum of individual benefits due to complex interaction of the building physics and its systems, deep BER packages were designed based on the investigated indicators. Table 9 shows the measures per technology type that comprise the deep retrofit packages as well as the required investment. The capital cost ratio between passive and active measures was found to be around $20 \%$ for both retrofit designs. 
Table 9 Deep energy retrofit characteristics for both buildings

\begin{tabular}{|c|c|c|c|c|}
\hline Technology & Primary School & $\begin{array}{l}\text { Investment } \\
(£)\end{array}$ & A/C Office & $\begin{array}{c}\text { Investment } \\
\text { (£) }\end{array}$ \\
\hline HVAC system & $\begin{array}{l}\text { Biomass Boiler } \\
\quad(194 \text { kW })\end{array}$ & $40,287.9$ & $\begin{array}{l}\text { GSHP } \\
(127 \mathrm{~kW})\end{array}$ & $153,388.9$ \\
\hline Emission system & VAV & 18,200 & LT Underfloor & 95,426 \\
\hline Insulation & $\begin{array}{c}\text { Glass fibre } \\
\text { Thickness: } 8.5 \mathrm{~cm}\end{array}$ & $20,813.4$ & $\begin{array}{c}\text { EPS } \\
\text { Thickness: } 7 \mathrm{~cm}\end{array}$ & 19,514 \\
\hline Glazing system & $\begin{array}{l}\text { Double pane } \\
\text { 13mm (air gap) }\end{array}$ & $47,324.5$ & $\begin{array}{l}\text { Double pane } \\
13 \mathrm{~mm} \text { (air gap) }\end{array}$ & 141,201 \\
\hline Sealing (ach) & 0.3 & $56,924.8$ & 0.4 & 54,327 \\
\hline Set-points (Heat/Cool) & 22 (no cooling) & -- & 21 and 24 & -- \\
\hline Lighting & LED & $128,829.5$ & LED & $177,343.8$ \\
\hline Renewable systems & $\begin{array}{c}\text { PV: } 25 \% \text { roof } \\
\left(216 \mathrm{~m}^{2}-43 \mathrm{kWp}\right) \\
\text { Wind: } 20 \mathrm{~kW}\end{array}$ & $\begin{array}{l}342,588 \\
80,000\end{array}$ & $\begin{array}{c}\text { PV: } 25 \% \text { roof } \\
\left(285 \mathrm{~m}^{2}-57 \mathrm{kWp}\right) \\
\text { Wind: } 20 \mathrm{~kW}\end{array}$ & $\begin{array}{l}259,200 \\
80,000\end{array}$ \\
\hline Total & & $734,968.1$ & & $980,401.3$ \\
\hline $\begin{array}{l}\text { Passive/Active } \\
\text { Investment Ratio }\end{array}$ & & 0.17 & & 0.22 \\
\hline
\end{tabular}

\subsubsection{Results}

Both packages achieved energy savings of around $70 \%$ and an improvement of thermal comfort of $66 \%$ and $22 \%$ for the school and office, respectively. In addition, reductions of exergy destructions were achieved at a rate of $48.9 \%$ for the school and $46.4 \%$ for the office. As shown in Fig. 15, exergy destruction cost rates were also minimised, promoting a reduction from $£ 2.89 / \mathrm{h}$ to $£ 1.28 / \mathrm{h}$ for the school (56\%) and from $£ 6.54 / \mathrm{h}$ to $£ 5.08 / \mathrm{h}$ for the office $(22 \%)$. 


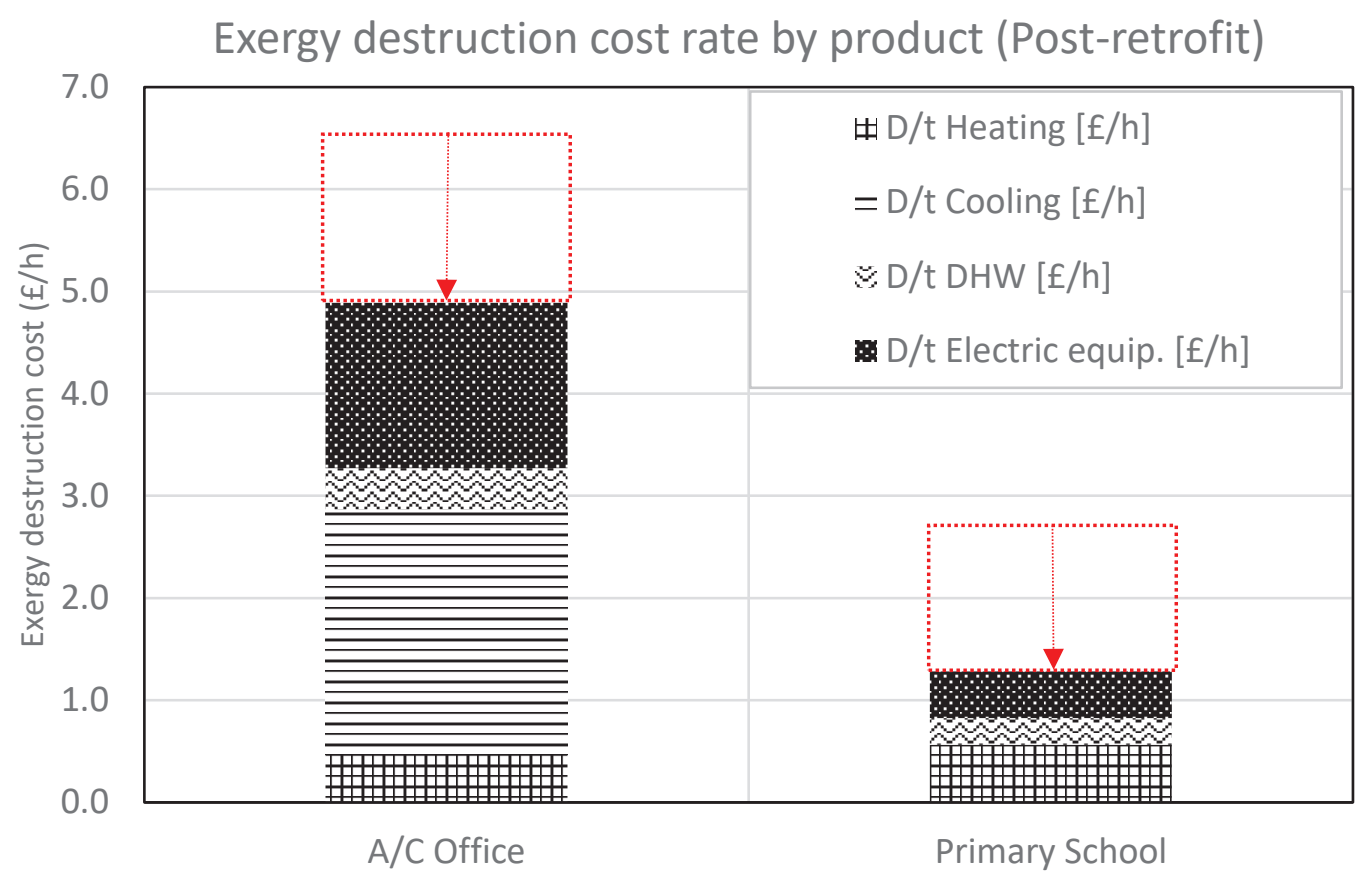

Fig. 15 Exergy destruction cost rate per product type (Post-retrofit)

The Exec $_{C B}$ indicator also presented a lower value than the baseline exergy destructions cost. Although in both cases, these were not as high as expected due to high capital investment ( $3369 / \mathrm{m}^{2}$ and $£ 379 / \mathrm{m}^{2}$ for the school and office, respectively) and a lower than expected annual revenue. For the school, the $\operatorname{Exec}_{C B}$ was $£ 1.96 / \mathrm{h}$ with a DPB of 84 years, while for the office the $\operatorname{Exec}_{C B}$ was $£ 5.07 / \mathrm{h}$ with a DPB of 61 years. These long payback periods show how typical economics does not account for exergy savings and exergy efficiency. This supports the case for developing exergy-based taxation and incentives, which will encourage the design of buildings with lower exergy destructions footprint. Overall, the proposed exergoeconomic cost-benefit indicator presented a good correlation with typical economic indicators, suggesting that the former could also be reliable for decision making.

Finally, Table 10 summarises all the main outputs for the combined measures compared against the baseline scenarios. As it can be noticed, thermodynamically deep BER designs were able to reduce final product price for heating and cooling streams. 
Table 10 A comparison of energy, exergy, and exergoeconomic values for pre-retrofit and post-retrofit buildings

\begin{tabular}{|c|c|c|c|c|c|c|}
\hline \multirow[b]{2}{*}{ Properties } & \multicolumn{3}{|c|}{ Primary School } & \multicolumn{3}{|c|}{ A/C Office } \\
\hline & Base Case & $\begin{array}{l}\text { Deep } \\
\text { Retrofit }\end{array}$ & $\begin{array}{c}\% \\
\text { Variation }\end{array}$ & Base Case & $\begin{array}{l}\text { Deep } \\
\text { Retrofit }\end{array}$ & $\begin{array}{c}\% \\
\text { Variation }\end{array}$ \\
\hline $\begin{array}{c}\text { Energy use (EUI) } \\
\left(k W h / m^{2}-y\right)\end{array}$ & 187.86 & 79.93 & -75.3 & 288.54 & 120.6 & -67.2 \\
\hline $\begin{array}{c}\text { Annual emissions } \\
\text { (TonCO2) }\end{array}$ & 214.8 & 20.9 & -90.3 & 285.6 & 133.9 & -53.1 \\
\hline $\begin{array}{c}\text { Thermal Discomfort } \\
\text { (hrs) }\end{array}$ & 1443 & 490 & -66.0 & 1414 & 1101 & -22.1 \\
\hline $\begin{array}{c}\text { Energy bill (after } \\
\text { incentives) } \\
\text { (£) }\end{array}$ & 19449.3 & -2121.1 & -110.1 & 59625.3 & 24494.7 & -58.9 \\
\hline $\begin{array}{l}\text { Exergy input } \\
\text { (MWh) }\end{array}$ & 533.0 & 276.8 & -48.1 & 1440.8 & 891.2 & -38.1 \\
\hline $\begin{array}{l}\text { Exergy destructions } \\
\text { (MWh) }\end{array}$ & 489.4 & 246.1 & -49.7 & 1228.2 & 713.2 & -41.9 \\
\hline $\begin{array}{c}\text { Exergy efficiency } \\
\text { HVAC }\end{array}$ & $1.5 \%$ & $2.6 \%$ & +1.1 & $5.1 \%$ & $15.9 \%$ & +10.8 \\
\hline $\begin{array}{c}\text { Exergy efficiency } \\
D H W\end{array}$ & $6.2 \%$ & $5.7 \%$ & -0.5 & $8.7 \%$ & $2.8 \%$ & -5.9 \\
\hline $\begin{array}{l}\text { Exergy efficiency } \\
\text { Electric equipment }\end{array}$ & $15.1 \%$ & $16.9 \%$ & +1.8 & $18.9 \%$ & $22.2 \%$ & +2.3 \\
\hline $\begin{array}{c}\text { Exergy efficiency } \\
\text { Whole Building }\end{array}$ & $8.2 \%$ & $11.1 \%$ & +2.9 & $14.8 \%$ & $20.0 \%$ & +5.2 \\
\hline $\begin{array}{c}\text { Exergy price fuel- } \\
\text { prod } H E A T(£ / k W h) \\
\left\{r_{k}\right\}\end{array}$ & $\begin{array}{c}0.03->1.86 \\
\{61.11\}\end{array}$ & $\begin{array}{c}0.04->1.29 \\
\{31.22\}\end{array}$ & -31.8 & $\begin{array}{c}0.03->0.45 \\
\quad\{13.86\}\end{array}$ & $\begin{array}{l}0.12->0.19 \\
\quad\{0.59\}\end{array}$ & -54.8 \\
\hline $\begin{array}{c}\text { Exergy price fuel- } \\
\text { prod COLD (£/kWh) } \\
\left\{r_{k}\right\}\end{array}$ & $-----\{---\}$ & $-----\{---\}$ & -- & $\begin{array}{c}0.12->3.11 \\
\{24.89\}\end{array}$ & $\begin{array}{c}0.12->0.47 \\
\quad\{2.90\}\end{array}$ & -84.8 \\
\hline $\begin{array}{c}\text { Exergy price fuel- } \\
\text { prod } D H W(£ / k W h) \\
\left\{r_{k}\right\}\end{array}$ & $\begin{array}{c}0.03->0.44 \\
\{13.72\}\end{array}$ & $\begin{array}{l}0.04->0.58 \\
\quad\{13.62\}\end{array}$ & +31.8 & $\begin{array}{l}0.03->0.55 \\
\quad\{17.49\}\end{array}$ & $\begin{array}{l}0.12->1.65 \\
\quad\{12.8\}\end{array}$ & +200.0 \\
\hline $\begin{array}{c}\text { Exergy price fuel- } \\
\text { prod Elec }(£ / k W h) \\
\left\{r_{k}\right\}\end{array}$ & $\begin{array}{l}0.12->0.31 \\
\quad\{1.60\}\end{array}$ & $\begin{array}{c}0.12->0.28 \\
\quad\{1.33\}\end{array}$ & -9.7 & $\begin{array}{l}0.12->0.25 \\
\quad\{1.07\}\end{array}$ & $\begin{array}{l}0.12->0.21 \\
\quad\{0.76\}\end{array}$ & -12.5 \\
\hline $\begin{array}{c}D \text { cost destructions } \\
(£ / h)\end{array}$ & 2.89 & 1.22 & -57.8 & 6.54 & 4.89 & -25.2 \\
\hline $\begin{array}{l}\text { Capital investment } \\
(£)\end{array}$ & -- & $£ 734,968.1$ & -- & -- & $£ 980,401.3$ & -- \\
\hline $\begin{array}{c}Z \\
(£ / h)\end{array}$ & -- & 3.15 & -- & -- & 4.20 & -- \\
\hline $\begin{array}{c}\text { Annual revenue } \\
(£ / h)\end{array}$ & -- & 2.46 & -- & -- & 4.01 & -- \\
\hline $\begin{array}{c}E x e c \_C B \\
(£ / h)\end{array}$ & -- & 1.96 & -- & -- & 5.08 & -- \\
\hline $\begin{array}{l}\text { Exergoeconomic } \\
\quad \text { factor } f_{k}(-)\end{array}$ & -- & 0.71 & -- & -- & 0.46 & -- \\
\hline
\end{tabular}




\section{Sensitivity Analysis}

\subsection{Post-parametric study ( $3^{\text {rd }}$ level)}

A sensitivity analysis was performed to explore further optimisation of design characteristics. For this particular analysis, the building wall insulation was varied leaving the rest of the envelope intact.

\section{School}

As a result of increasing the glass fibre insulation thickness, an increment in total capital investment was obtained, even with the biomass boiler size reduction due to a lower energy demand(Fig. 16). Added to this, a slight reduction in discomfort hours was obtained.

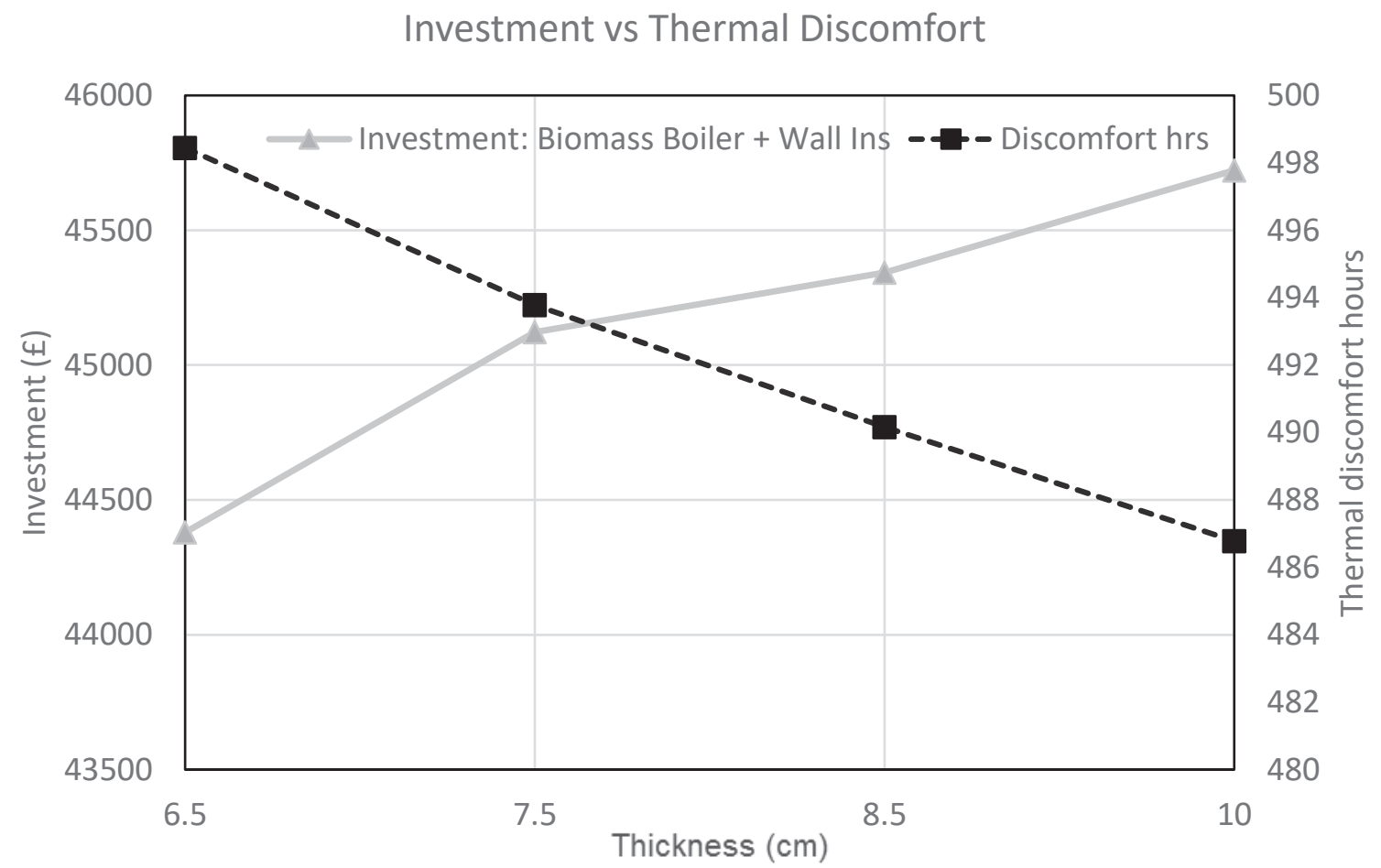

Fig. 16 Sensitivity analysis of glass fibre wall insulation for the School case. Investment and Discomfort hours

By increasing the insulation, a minimisation in both the energy use and exergy destructions was achieved (Fig. 17). The exergy destruction cost for heating ranges from $£ 0.57 / \mathrm{h}$ for the lowest value of insulation to $£ 0.53 / \mathrm{h}$ for $0.10 \mathrm{~m}$. 


\section{Energy use vs Exergy destructions}

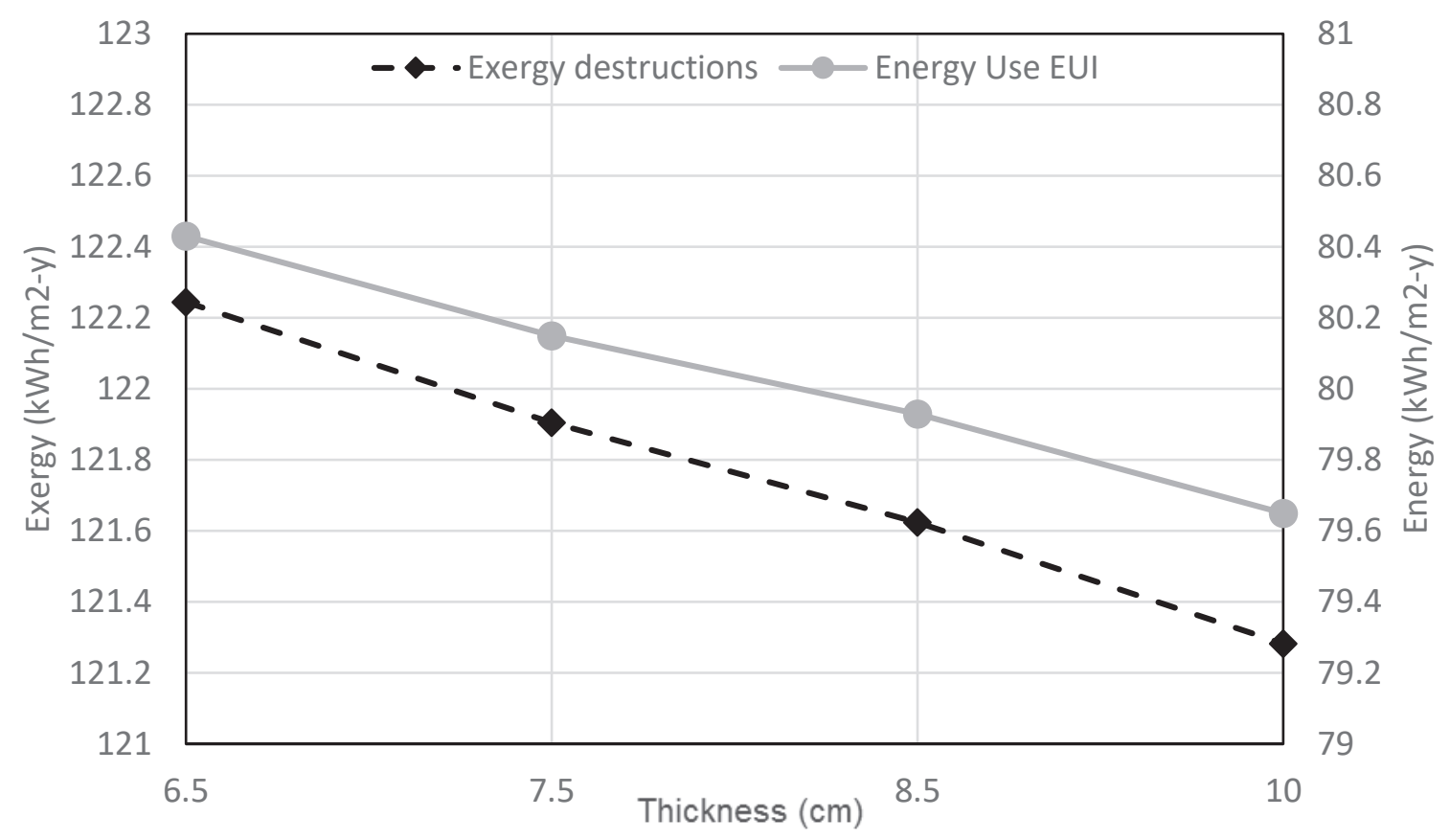

Fig. 17 Sensitivity analysis of glass fibre wall insulation for the School case. Energy use vs Exergy destructions

\section{Office}

For the office, the outputs are slightly different. By increasing the insulation, the total investment cost is reduced as the capital cost savings from downsizing the GSHP equipment exceed the extra investment for thicker insulation (Fig. 18). At $0.07 \mathrm{~m}$ of EPS, the GSHP had a capacity of $127 \mathrm{~kW}$, while for $0.15 \mathrm{~m}$ of EPS, the GSHP size is reduced to $119 \mathrm{~kW}$, requiring a lower investment cost. However, this increase in insulation negatively impacts thermal comfort due to overheating during summer months. However, DBPs are very similar for both extreme cases, ranging from 64 years for the lowest thickness to 60 years for the highest insulation level. 


\section{Investment and thermal discomfort}

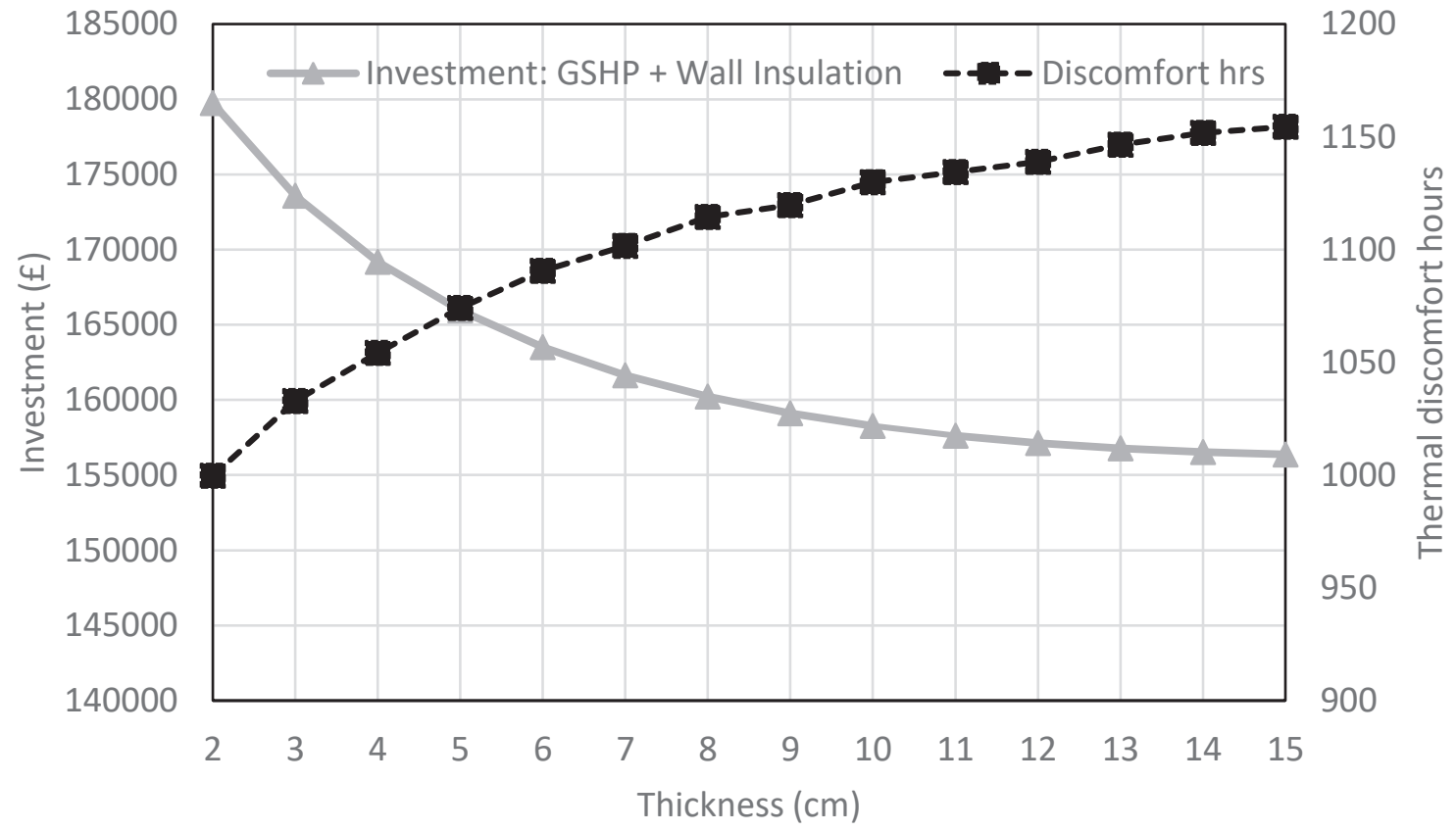

Fig. 18 Sensitivity analysis of EPS wall insulation for the Office case. Investment and Discomfort hours

Fig. 19 shows different behaviours for energy use and exergy destructions. On one hand, the increase of insulation leads to the reduction in total energy use, where savings in electricity for the operation of the heat pump in heating mode are greater than the increase of electrical demand for cooling. On the other hand, this is the opposite in exergy terms. An increase in electrical demand for cooling presents larger irreversibilities than exergy savings in the heating process, due to the lower exergetic efficiency for cooling processes in a temperate climate such as London. Therefore, other passive strategies such as natural ventilation or night cooling should be pursued to lower exergetic demand and increase efficiency. By decreasing insulation thickness from $0.07 \mathrm{~m}$ to $0.02 \mathrm{~m}$, an increase in exergy efficiency from $18.3 \%$ to $18.9 \%$ could be achieved. In addition, the exergy destruction cost for the heating and cooling products combined is proportional to thickness insulation increase, going from $£ 1.83 / \mathrm{h}$ for $0.02 \mathrm{~m}$ to $£ 2.19 / \mathrm{h}$ for $0.15 \mathrm{~m}$. 


\section{Energy use vs Exergy destructions}

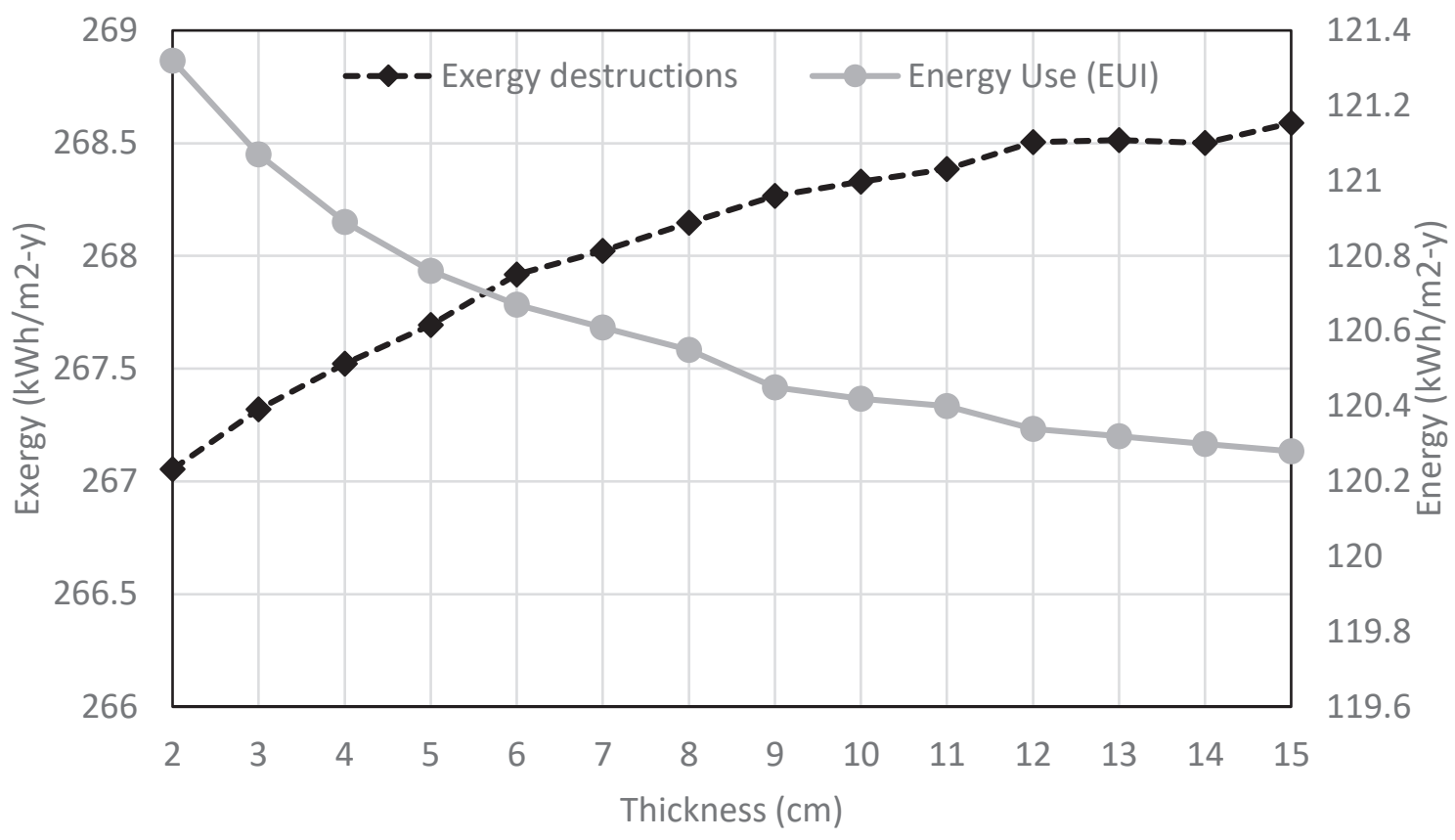

Fig. 19 Sensitivity analysis of glass fibre wall insulation for the Office case. Energy use vs Exergy destructions

\section{Conclusions}

Selecting BER measures that are able to deliver high exergy efficiency combined with low capital cost and high return of investment is still a challenge. This paper presented a way by which exergoeconomics could be integrated as a valuable decision-making support tool for improving BER design. The proposed method embeds thermoeconomic theory into BER practice through the development and integration of an exergoeconomic module into a retrofit oriented building simulation tool. In addition to this, a novel exergoeconomic cost benefit indicator, that considers the economics of energy use, the cost of exergy destruction, and the capital and revenue costs due to energy savings, was presented.

In typical practice, it is believed that buildings with better performance are those who tend to have a good passive design and a tighter envelope. But the results obtained for the specific case studies showed that active components (especially HVAC systems) have better energy, economic, exergy, and exergoeconomic performance, and are therefore more likely to improve overall thermodynamic performance. For this reason, before any major passive refurbishment is undertaken, findings suggest that active measures should be first considered. 
Furthermore, deep energy/exergy retrofits were designed based on the developed exergoeconomic index. The office deep-BER achieved improvements in energy use of $67 \%$, $\mathrm{CO}_{2}$ emissions by $53 \%$, thermal comfort by $22 \%$, and reductions of exergy destructions by $42 \%$. Also, overall exergy efficiency was improved from $14.8 \%$ to $20.4 \%$. The school case presented similar results with the potential to generate income thanks to government incentives $(\mathrm{RHI})$. School building exergy efficiency was improved from $8.2 \%$ to $11.1 \%$. In both cases, final product cost for heating and cooling were notably reduced.

However, to achieve high thermodynamic performance, high capital investments were required showing that low exergy equipment is still expensive under current market conditions. For example, district systems do not seem economically viable due to lack of government incentives. In this sense, exergy based taxation and incentives could help unlock unconventional technologies and provide more flexibility in the design process, where high performance buildings combined with low exergy supply structures are key for a future sustainable development of the building sector. Other similar low exergy systems that showed high capital prices in the current market are heat pumps that work with low temperature lifting. Model exergy outputs showed that CHP and PV/T products, especially electricity, need to be used correctly, considering a supply-demand quality match in the design. Using electricity for space conditioning is a practice that should be avoided and heavily penalised. Finally, a postparametric sensitivity analysis on the wall insulation thickness was performed to investigate the potential for additional improvement.

Exergoeconomics can be integrated into the design of BERs to provide more sustainable and efficient solutions. Further work in this area will integrate the developed exergoeconomic module into a multi-objective optimisation platform which will allow the modeller to perform a deeper exploration, and expect to achieve better solutions under energy, exergy, economic, and exergoeconomic objectives. In addition, further research will involve the application of the tool to real buildings. Finally, as part of the model's constant development, it is intended to verify and validate the outputs with similar studies.

\section{Acknowledgments}

The first author acknowledges support from The Mexican National Council for Science and Technology (CONACyT) through a scholarship to pursue doctoral studies with a CVU: 331698 and grant number: 217593 .

\section{Nomenclature}

A area $\left(\mathrm{m}^{2}\right)$ 


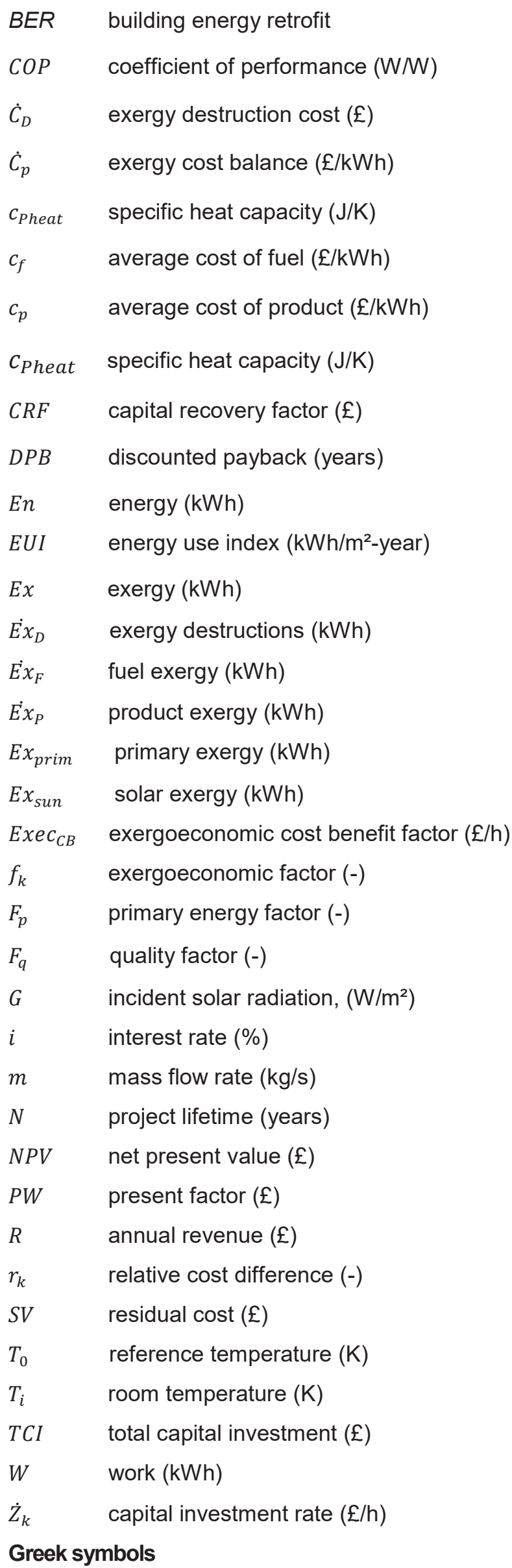




\begin{tabular}{|ll|}
$\eta_{\text {gen }}$ & energy efficiency (-) \\
$\psi_{\text {tot }}$ & exergy efficiency (-) \\
Subscripts and superscripts \\
col & collector \\
cook & cooking \\
dem & demand \\
$d h w$ & domestic hot water \\
elec & electricity \\
gen & generation system \\
$h v a c$ & heating, ventilation, and air conditioning \\
$i$ & i zone, equipment or energy source \\
$k$ & building subsystem or component \\
prim & primary energy \\
$P V$ & photovoltaic \\
sun & sun \\
$t_{k}$ & time step \\
therm & thermal demand \\
\hline
\end{tabular}

\section{Appendix A. Exergy analysis for renewable-based equipment}

Direct solar systems:

To calculate the exergy of the incoming solar radiation $E x_{\text {sun }}$ to the equipment the following formula is used:

$$
E x_{\text {sun }}\left(t_{k}\right)=G\left(t_{k}\right) * A_{\text {col }} *\left(1-\frac{T_{0}\left(t_{k}\right)}{T_{\text {sun }}}\right)
$$

where $G$ is the incident solar radiation, $A_{c o l}$ is the collector surface area, $T_{0}$ is the reference environment, and $T_{\text {sun }}$ is the sun's temperature, which is taken as $6000 \mathrm{~K}$. Hence, the output of the collector $E x_{c o l}$ is the generation subsystem output and is calculated as follows:

$E x_{\text {col }}\left(t_{k}\right)=\dot{m}\left(t_{k}\right) * c_{\text {Pheat }}\left[\left(T_{\text {out }}\left(t_{k}\right)-T_{\text {in }}\left(t_{k}\right)-T_{0}\left(t_{k}\right) * \ln \left(\frac{T_{\text {out }}\left(t_{k}\right)}{T_{\text {in }}\left(t_{k}\right)}\right)\right]\right.$

where $\dot{m}$ is the mass flow rate $(\mathrm{kg} / \mathrm{s}), c_{\text {Pheat }}$ is the carrier specific heat, $T_{\text {out }}$ is the temperature provided by the collector, and $T_{\text {in }}$ the return temperature to the collector. Finally, the exergy efficiency for solar collectors $\Psi_{c o l}$ is obtained as follows:

$\Psi_{\text {col }}\left(t_{k}\right)=\frac{E x_{\text {col }}\left(t_{k}\right)}{E x_{\text {sun }}\left(t_{k}\right)}$

For hybrid PV/T panels, exergy efficiency $\Psi_{P V T}$ is calculated as follows: 
$\Psi_{P V T}\left(t_{k}\right)=\frac{E_{P V}\left(t_{k}\right)+E x_{c o l}\left(t_{k}\right)}{E x_{\text {sun }}\left(t_{k}\right)}$

where $E_{P V}$ is the electrical energy generated by the panel (which has the same exergy value), $E x_{c o l}$ is the thermal exergy output, and $E x_{\text {sun }}$ is the incoming solar radiation.

Heat Pumps:

For heat pumps, we use the formula that only accounts for the exergy coming from electricity, thus the exergy content of the reservoir is considered as free exergy. Therefore, the efficiency $\Psi_{H P}$ is calculated as follows:

$\Psi_{H P}\left(t_{k}\right)=\frac{E x_{\text {th.dem }}}{W}=\frac{\sum_{i=1}^{n}\left(E n_{\text {th,dem } i}\left(t_{k}\right) *\left(1-\frac{T_{0}\left(t_{k}\right)}{T_{i}\left(t_{k}\right)}\right)\right)}{W\left(t_{k}\right)}=\operatorname{COP}\left(t_{k}\right) *\left(1-\frac{T_{0}\left(t_{k}\right)}{T_{i}\left(t_{k}\right)}\right)$

Where $E x_{\text {th.dem }}$ is the building thermal exergy demand, $W$ is the electrical power input, $E n_{t h, d e m}$ is the building thermal energy demand, $T_{0}$ is the reference temperature, $T_{i}$ is the internal temperature, and $C O P$ is the heat pump coefficient of performance.

\section{Appendix B. Characteristics of building retrofit measures}

Table B.1 Characteristics and investment cost of HVAC systems

\begin{tabular}{|c|c|c|c|}
\hline $\begin{array}{l}\text { HVAC } \\
\text { ID }\end{array}$ & System Description & $\begin{array}{l}\text { Emission } \\
\text { system }\end{array}$ & Cost \\
\hline $\mathrm{H} 1$ & Condensing Gas Boiler + Chiller & CAV & Generation systems \\
\hline $\mathrm{H} 2$ & Condensing Gas Boiler + Chiller & VAV & - $£ 160 / \mathrm{kW}$ Water-based \\
\hline $\mathrm{H} 3$ & $\begin{array}{l}\text { Condensing Gas Boiler + ASHP-VRF } \\
\text { System }\end{array}$ & $\mathrm{FC}$ & - $\quad$ Chiller $(\mathrm{COP}=3.2)$ \\
\hline $\mathrm{H} 4$ & Oil Boiler + Chiller & CAV & boiler $(n=0.95)$ \\
\hline H5 & Oil Boiler + Chiller & VAV & - $\quad £ 70 / \mathrm{kW}$ \\
\hline $\mathrm{H} 6$ & Oil Boiler + Chiller & $\mathrm{FC}$ & $£ 150 / \mathrm{kW}$ Electric Boiler \\
\hline $\mathrm{H} 7$ & Electric Boiler + Chiller & CAV & $(\eta=1.0)$ \\
\hline $\mathrm{H} 8$ & Electric Boiler + Chiller & VAV & - $\quad £ 208 / \mathrm{kW}$ Biomass Boiler \\
\hline $\mathrm{H} 9$ & Electric Boiler + ASHP-VRF System & FC & $(\eta=0.90)$ \\
\hline $\mathrm{H} 10$ & Biomass Boiler + Chiller & CAV & - $\quad £ 1300 / \mathrm{kW}$ ASHP-VRF \\
\hline $\mathrm{H} 11$ & Biomass Boiler + Chiller & VAV & $£ 1200 / \mathrm{kW} \quad$ GSHP \\
\hline $\mathrm{H} 12$ & Biomass Boiler + ASHP-VRF System & $\mathrm{FC}$ & (Water-Water) \\
\hline $\mathrm{H} 13$ & District system & CAV & $(\mathrm{COP}=4.2)$ \\
\hline $\mathrm{H} 14$ & District system & VAV & - $\quad £ 452 / \mathrm{kW}$ ASHP (Air-Air) \\
\hline $\mathrm{H} 15$ & District system & Wall & $\begin{array}{l}(\mathrm{COP}=3.2) \\
\text { - } \quad 2000 / \mathrm{kW} \text { PV-T system }\end{array}$ \\
\hline $\mathrm{H} 16$ & District system & Underfloor & - $\quad £ 27,080$ micro-CHP (5.5 \\
\hline $\mathrm{H} 17$ & District system & Wall+Underfloor & $\mathrm{kW})+$ fuel cell system \\
\hline $\mathrm{H} 18$ & Ground Source Heat Pump & CAV & \\
\hline $\mathrm{H} 19$ & Ground Source Heat Pump & VAV & Emission systems \\
\hline $\mathrm{H} 2 \mathrm{O}$ & Ground Source Heat Pump & Wall & \\
\hline
\end{tabular}




\begin{tabular}{|c|c|c|c|}
\hline H21 & Ground Source Heat Pump & Underfloor & - $\quad £ 1200$ per VAV \\
\hline $\mathrm{H} 22$ & Ground Source Heat Pump & Wall+Underfloor & - $\quad £ 35 / \mathrm{m}^{2}$ wall heating \\
\hline $\mathrm{H} 23$ & Air Source Heat Pump & CAV & - $\quad £ 35 / \mathrm{m}^{2} \quad$ underfloor \\
\hline 24 & $\begin{array}{l}\text { PVT-based system (50\% roof) with } \\
\text { supplemental Electric boiler and Old Chiller }\end{array}$ & CAV & $\begin{array}{l}\text { heating } \\
\qquad 6117\end{array}$ \\
\hline 25 & Condensing Boiler + Chiller & Wall & Recovery system \\
\hline 26 & Condensing Boiler + Chiller & Underfloor & \\
\hline 27 & Condensing Boiler + Chiller & Wall+Underfloor & $£ 56 / \mathrm{kW}$ District \\
\hline 28 & Biomass Boiler + Chiller & Wall & exchanger $+£ 6122$ \\
\hline 29 & Biomass Boiler + Chiller & Underfloor & connection charge \\
\hline 30 & Biomass Boiler + Chiller & Wall+Underfloor & - $\quad £ 50 / m$ for building's \\
\hline H31 & $\begin{array}{l}\text { Micro-CHP with Fuel Cell and Electric boiler } \\
\text { and old Chiller }\end{array}$ & CAV & $\begin{array}{l}\text { insulated } \\
\text { pipes }\end{array}$ \\
\hline 32 & $\begin{array}{l}\text { Condensing Gas Boiler and old Chiller. Heat } \\
\text { Recovery System included. }\end{array}$ & CAV & \\
\hline
\end{tabular}

Table B.2 Characteristics and investment cost of lighting systems

\begin{tabular}{ccc}
\hline $\begin{array}{c}\text { Lights } \\
\text { ID }\end{array}$ & $\begin{array}{c}\text { Lighting } \\
\text { technology }\end{array}$ & $\begin{array}{c}\text { Cost per } \\
\mathbf{W} / \mathbf{m}^{2}\end{array}$ \\
\hline L1 & $T 8 L F C$ & $£ 5.55$ \\
L2 & $T 5 L F C$ & $£ 7.55$ \\
L3 & $T 8 L E D$ & $£ 11.87$ \\
\hline
\end{tabular}

Table B.3 Characteristics and investment cost of renewable energy generation systems

\begin{tabular}{ccc}
\hline Renewable & Technology & Cost \\
\hline R1 & $P V$ panels $25 \%$ roof & PV: $£ 1200 / \mathrm{m}^{2}$ \\
R2 & $P V$ panels $50 \%$ roof & \\
R3 & $P V$ panels $75 \%$ roof & \\
R4 & Wind Turbine $20 \mathrm{~kW}$ & Turbine: $£ 4000 / \mathrm{kW}$ \\
R5 & Wind Turbine $40 \mathrm{~kW}$ & \\
\hline
\end{tabular}

Table B.4 Characteristics and investment cost of different insulation materials

\begin{tabular}{|c|c|c|c|c|}
\hline $\begin{array}{l}\text { Ins. } \\
\text { ID }\end{array}$ & Insulation measure & $\begin{array}{l}\text { Thickness } \\
\text { (cm) }\end{array}$ & $\begin{array}{c}\text { Total of } \\
\text { measures }\end{array}$ & $\begin{array}{c}\text { Cost per } \mathrm{m}^{2} \\
\text { (lowest to highest) }\end{array}$ \\
\hline 11 & Polyurethane & 2 to 15 in $1 \mathrm{~cm}$ steps & 14 & $£ 6.67$ to $£ 23.32$ \\
\hline 12 & Extruded polystyrene & 1 to 15 in $1 \mathrm{~cm}$ steps & 15 & $£ 4.77$ to $£ 31.99$ \\
\hline 13 & Expanded polystyrene & 2 to 15 in $1 \mathrm{~cm}$ steps & 14 & $£ 4.35$ to $£ 9.95$ \\
\hline 14 & Cellular Glass & 4 to 18 in $1 \mathrm{~cm}$ steps & 15 & $£ 16.21$ to $£ 72.94$ \\
\hline 15 & Glass Fibre & $\begin{array}{l}6.7,7.5,8.5, \text { and } 10 \mathrm{~cm} \\
2 \text { to } 6 \text { in } 1 \mathrm{~cm} \text { steps, }\end{array}$ & 4 & $£ 5.65$ to $£ 7.75$ \\
\hline 16 & Cork board & $\begin{array}{c}8 \text { to } 20 \mathrm{~cm} \text { in } 2 \mathrm{~cm} \text { steps, } \\
28 \text { and } 30 \mathrm{~cm}\end{array}$ & 14 & $£ 5.57$ to $£ 85.80$ \\
\hline 17 & Phenolic foam board & 2 to 10 in $1 \mathrm{~cm}$ steps & 9 & $£ 5.58$ to $£ 21.89$ \\
\hline 18 & Aerogel & 0.5 to 4 in $0.5 \mathrm{~cm}$ steps & 8 & $£ 26.80$ to $£ 195.14$ \\
\hline 19 & PCM (w/board) & 10 and $20 \mathrm{~mm}$ & 2 & $£ 57.75$ to $£ 107.75$ \\
\hline
\end{tabular}


Table B.5 Characteristics and investment cost of glazing systems

\begin{tabular}{cccc}
\hline $\begin{array}{c}\text { Glazing } \\
\text { ID }\end{array}$ & $\begin{array}{c}\text { System Description } \\
\text { (\# panes - gap) }\end{array}$ & $\begin{array}{c}\text { Gas } \\
\text { Filling }\end{array}$ & Cost per $\mathbf{~ m}^{\mathbf{2}}$ \\
\hline G1 & Double pane $-6 \mathrm{~mm}$ & Air & $£ 261$ \\
G2 & Double pane $-13 \mathrm{~mm}$ & Air & $£ 261$ \\
G3 & Double pane $-6 \mathrm{~mm}$ & Argon & $£ 350$ \\
G4 & Double pane $-13 \mathrm{~mm}$ & Argon & $£ 350$ \\
G5 & Double pane $-6 \mathrm{~mm}$ & Krypton & $£ 370$ \\
G6 & Double pane $-13 \mathrm{~mm}$ & Krypton & $£ 370$ \\
G7 & Triple pane $-6 \mathrm{~mm}$ & Air & $£ 467$ \\
G8 & Triple pane $-13 \mathrm{~mm}$ & Air & $£ 467$ \\
G9 & Triple pane $-6 \mathrm{~mm}$ & Argon & $£ 613$ \\
G10 & Triple pane $-13 \mathrm{~mm}$ & Argon & $£ 613$ \\
G11 & Triple pane $-6 \mathrm{~mm}$ & Krypton & $£ 653$ \\
G12 & Triple pane $-13 \mathrm{~mm}$ & Krypton & $£ 653$ \\
\hline
\end{tabular}

Table B.6 Characteristics and investment cost for air tightness improvement considering

\begin{tabular}{ccc}
\multicolumn{3}{c}{ baseline of 1 ach } \\
\hline Sealing ID & $\begin{array}{c}\text { ACH (1/h) } \\
\text { Improvement \% }\end{array}$ & $\begin{array}{c}\text { Cost per } \mathbf{~ m}^{\mathbf{2}} \\
\text { (opaque } \\
\text { envelope) }\end{array}$ \\
\hline S1 & $10 \%$ & $£ 1.20$ \\
S2 & $20 \%$ & $£ 3.31$ \\
S3 & $30 \%$ & $£ 6.35$ \\
S4 & $40 \%$ & $£ 10.30$ \\
S5 & $50 \%$ & $£ 15.20$ \\
S6 & $60 \%$ & $£ 20.98$ \\
S7 & $70 \%$ & $£ 27.69$ \\
S8 & $80 \%$ & $£ 35.33$ \\
S9 & $90 \%$ & $£ 43.88$ \\
\hline
\end{tabular}

Table B.7 Cooling and heating indoor set points variations

\begin{tabular}{cccc}
\hline Set-point ID & Set-point Type & Value $\left({ }^{\circ} \mathbf{C}\right)$ & Cost \\
\hline SH18 & Heating & 18 & $(-)$ \\
SH19 & & 19 & \\
SH20 & & 20 & \\
SH21 & & 21 & \\
SH22 & & 22 & \\
SC23 & Cooling & 23 & $(-)$ \\
SC24 & & 24 & \\
SC25 & & 25 & \\
SC26 & & 26 & \\
SC27 & & 27 & \\
\hline
\end{tabular}

\section{References}

[1] DECC. Energy Consumption in the UK In: DECC, editor. UK2014.

[2] ARUP. Low Carbon Routemap for the UK Built Environment. In: Board TGC, editor. UK2013.

[3] Meggers F, Ritter V, Goffin P, Baetschmann M, Leibundgut H. Low exergy building systems implementation. Energy. 2012;41:48-55. 
[4] Nagy Z, Rossi D, Hersberger C, Irigoyen SD, Miller C, Schlueter A. Balancing envelope and heating system parameters for zero emissions retrofit using building sensor data. Applied Energy. 2014;131:56-66.

[5] Hepbasli A. Low exergy (LowEx) heating and cooling systems for sustainable buildings and societies. Renewable and Sustainable Energy Reviews. 2012;16:73-104.

[6] Shukuya M, Hammache A. Introduction to the Concept of Exergy - for a Better Understanding of Low-Temperature-Heating and High-Temperature-Cooling Systems. Submitted to IEA ANNEX37 "Low Exergy Systems for Heating and Cooling of Buildings". 2002.

[7] Schmidt D. Methodology for the Modelling of Thermally Activated Building Components in Low Exergy Design [PhD Thesis]. Sweden: Kungliga Tekniska Högskolan; 2004.

[8] Torio H. Comparison and optimization of building energy supply systems through exergy analysis and its perspectives: Fraunhofer; 2012.

[9] Jansen SC, Terés-Zubiaga J, Luscuere PG. The exergy approach for evaluating and developing an energy system for a social dwelling. Energy and Buildings. 2012;55:693-703.

[10] Terés-Zubiaga J, Jansen SC, Luscuere P, Sala JM. Dynamic exergy analysis of energy systems for a social dwelling and exergy based system improvement. Energy and Buildings. 2013;64:359-71.

[11] Ferreira Goncalves PM. Energy and exergy assessments for an enhanced use of energy in buildings: Universidade de Coimbra; 2013.

[12] H. Esen, M. Inalli, M. Esen, K. Pihtili, Energy and exergy analysis of a ground-coupled heat pump system with two horizontal ground heat exchangers, Building and Environment, 42 (10) (2007) 36063615.

[13] Gonçalves P, Gaspar AR, da Silva MG. Comparative energy and exergy performance of heating options in buildings under different climatic conditions. Energy and Buildings. 2013;61:288-97.

[14] Khalid F, Dincer I, Rosen MA. Development and analysis of sustainable energy systems for building HVAC applications. Applied Thermal Engineering. 2015;87:389-401.

[15] Açıkkalp E, Hepbasli A, Yucer CT, Karakoc TH. Advanced exergoenvironmental assessment of a building from the primary energy transformation to the environment. Energy and Buildings. 2015;89:1-8.

[16] H. Esen, M. Inalli, M. Esen, Technoeconomic appraisal of a ground source heat pump system for a heating season in eastern Turkey, Energy Conversion and Management, 47 (9-10) (2006) 1281-1297. [17] Menassa CC. Evaluating sustainable retrofits in existing buildings under uncertainty. Energy and Buildings. 2011;43:3576-83.

[18] Ashuri B, Kashani H, Lu J. An Investment Analysis Framework for Energy Retrofit in Existing Buildings. 47th ASC Annual International Conference Proceedings. 2011:9.

[19] Valero A, Torres C. Thermoeconomic Analysis. In: Frangopoulosaylo CA, editor. Exergy, energy system analysis, and optimization: EOLSS; 2009. p. 454.

[20] Tsatsaronis G. Thermoeconomic analysis and optimization of energy systems. Progress in Energy and Combustion Science. 1993;19:227-57.

[21] Dincer I, Zamfirescu C. Sustainable Energy Systems and Applications. US: Springer 2012.

[22] Müller A, Kranzl L, Tuominen P, Boelman E, Molinari M, Entrop AG. Estimating exergy prices for energy carriers in heating systems: Country analyses of exergy substitution with capital expenditures. Energy and Buildings. 2011;43:3609-17.

[23] Yücer CT, Hepbasli A. Exergoeconomic and enviroeconomic analyses of a building heating system using SPECO and Lowex methods. Energy and Buildings. 2014;73:1-6.

[24] Tozer R, Lozano Serrano MA, Valero Capilla A, James R. Thermoeconomics applied to an air conditioning system with cogeneration. Building Services Engineering Research and Technology. 1996;17:37-42.

[25] Caliskan H, Dincer I, Hepbasli A. Thermoeconomic analysis of a building energy system integrated with energy storage options. Energy Conversion and Management. 2013;76:274-81. 
[26] Pirkandi J, Jokar MA, Sameti M, Kasaeian A, Kasaeian F. Simulation and multi-objective optimization of a combined heat and power (CHP) system integrated with low-energy buildings. Journal of Building Engineering. 2016;5:13-23.

[27] Fan B, Jin X, Fang X, Du Z. The method of evaluating operation performance of HVAC system based on exergy analysis. Energy and Buildings. 2014;77:332-42.

[28] Hassoun A, Dincer I. Analysis and performance assessment of a new multigeneration system for net-zero energy houses. International Journal of Energy Research. 2016;40:36-50.

[29] Verda V, Kona A. Thermoeconomics as a tool for the design and analysis of energy savings initiatives in buildings connected to district heating networks. International Journal of Thermodynamics 2012;15:221-9.

[30] Ucar A. Thermoeconomic analysis method for optimization of insulation thickness for the four different climatic regions of Turkey. Energy. 2010;35:1854-64.

[31] Campos-Celador Á, Pérez-Iribarren E, Sala JM, del Portillo-Valdés LA. Thermoeconomic analysis of a micro-CHP installation in a tertiary sector building through dynamic simulation. Energy. 2012;45:228-36.

[32] Demirel Y, Öztürk HH. Thermoeconomics of seasonal latent heat storage system. International Journal of Energy Research. 2006;30:1001-12.

[33] Lee SH, Hong T, Piette MA, Taylor-Lange SC. Energy retrofit analysis toolkits for commercial buildings: A review. Energy. 2015;89:1087-100.

[34] Sakulpipatsin P. Exergy efficient building design [PhD Thesis]: Technische Universiteit Delft; 2008.

[35] Schlueter A, Thesseling F. Building information model based energy/exergy performance assessment in early design stages. Automation in Construction. 2009;18:153-63.

[36] ECB-Annex49. Detailed Exergy Assessment Guidebook for the Built Environment, IEA ECBCS. In: Torio H, Schmidt D, editors.: Fraunhofer IBP; 2011.

[37] García Kerdan I, Raslan R, Ruyssevelt P. An exergy-based multi-objective optimisation model for energy retrofit strategies in non-domestic buildings. Energy. 2016. Article in Press (http://dx.doi.org/10.1016/j.energy.2016.06.041)

[38] EnergyPlus. EnergyPlus Engineering Reference. 2012. p. 1278.

[39] Rosen M, Bulucea CA. Using Exergy to Understand and Improve the Efficiency of Electrical Power Technologies. Entropy. 2009;11:820-35.

[40] O. Ozgener, L. Ozgener, Exergy and reliability analysis of wind turbine systems: A case study, Renewable and Sustainable Energy Reviews, 11 (8) (2007) 1811-1826.

[41] K. Pope, I. Dincer, G.F. Naterer, Energy and exergy efficiency comparison of horizontal and vertical axis wind turbines, Renewable Energy, 35 (9) (2010) 2102-2113.

[42] Z. Wei, R. Zmeureanu, Exergy analysis of variable air volume systems for an office building, Energy Conversion and Management, 50 (2) (2009) 387-392.

[43] AMCA, AMCA's Fan Efficiency Grades: Answers to Frequently Asked Questions, in, Arlington Hts., Illinois, 2011.

[44] L. Gasser, B. Wellig, K. Hilfiker, WEXA: Exergy analysis for increasing the efficiency of air/water heat pumps in: S.F.O.o. Energy (Ed.), Lucerne University of Applied Sciences and Arts - Engineering \& Architecture 2008.

[45] Pout CH. Proposed Carbon Emission Factors and Primary Energy Factors for SAP 2012. In: BRE, editor. Techical papers supporting SAP 2012. UK2011.

[46] Torío H, Angelotti A, Schmidt D. Exergy analysis of renewable energy-based climatisation systems for buildings: A critical view. Energy and Buildings. 2009;41:248-71.

[47] Pons M. On the Reference State for Exergy when Ambient Temperature Fluctuates. International Journal of Thermodynamics. 2009;12:113-21.

[48] Angelotti A, Caputo P, Solani G. Dynamic exergy analysis of an air source heat pump. 1st International Exergy, Life Cycle Assessment, and Sustainability Workshop \& Symposium (ELCAS). 2009:8. 
[49] Zhou Y, Gong G. Exergy analysis of the building heating and cooling system from the power plant to the building envelop with hourly variable reference state. Energy and Buildings. 2013;56:94-9.

[50] Alpuche MG, Heard C, Best R, Rojas J. Exergy analysis of air cooling systems in buildings in hot humid climates. Applied Thermal Engineering. 2005;25:507-17.

[51] Zhang Y, Korolija I. Performing complex parametric simulations with jEPlus. SET2010 - 9th International Conference on Sustainable Energy Technologies. Shanghai, China2010.

[52] AECOM. Spon's Architects' and Builders' Price Book. 140th ed: Taylor \& Francis Group; 2015.

[53] AECOM. Spon's Mechanical and Electrical Services Price Book. 46th ed: Taylor \& Francis Group; 2015.

[54] DECC. Research on the costs and performance of heating and cooling technologies

URL: https://www.gov.uk/government/uploads Accesed: 11-Oct-2015.

[55] NREL. URL: http://www.nrel.gov/ap/retrofits/group_listing.cfm Accesed: 15-Oct-2015.

[56] ReedBusinessInformation. RSMeans Construction Data.

URL: http://www.rsmeans.com/index.asp, Accessed: 6 Oct 2015.

[57] JustInsulation. URL: http://www.just-insulation.com/002-brands, Accesed: 10-Oct-2015.

[58] Asadi E, Silva MGd, Antunes CH, Dias L, Glicksman L. Multi-objective optimization for building retrofit: A model using genetic algorithm and artificial neural network and an application. Energy and Buildings. 2014;81:444-56.

[59] Shao Y, Geyer P, Lang W. Integrating requirement analysis and multi-objective optimization for office building energy retrofit strategies. Energy and Buildings. 2014;82:356-68.

[60] HM_Treasury. THE GREEN BOOK: Appraisal and Evaluation in Central Government. In: Treasury $H$, editor. London, UK2003.

[61] Rysanek AM, Choudhary R. Optimum building energy retrofits under technical and economic uncertainty. Energy and Buildings. 2013;57:324-37.

[62] DECC. Quarterly Energy Prices September 2015. In: Publication ANS, editor. UK2015.

[63] Rosen MA. A concise review of exergy-based economic methods. Proceedings of the 3rd IASME/WSEAS international conference on Energy \\& environment. Cambridge, UK: World Scientific and Engineering Academy and Society (WSEAS); 2008. p. 136-44.

[64] Lazzaretto A, Tsatsaronis G. SPECO: A systematic and general methodology for calculating efficiencies and costs in thermal systems. Energy. 2006;31:1257-89.

[65] I. Baldvinsson, T. Nakata, A comparative exergy and exergoeconomic analysis of a residential heat supply system paradigm of Japan and local source based district heating system using SPECO (specific exergy cost) method, Energy, 74 (2014) 537-554.

[66] ASHRAE. ANSI/ASHRAE Standard 55-2004. Thermal Environmental Conditions for Human Occupancy. American Society of Heating, Refrigerating and Air-conditioning Engineers; 2004.

[67] Rickaby P, Gorgolewski M. A classification system for services in nondomestic buildings. Environment and Planning B: Planning and Design. 2000;27:695-708.

[68] Godoy-Shimizu D, Armitage P, Steemers K, Chenvidyakarn T. Using Display Energy Certificates to quantify schools' energy consumption. Building Research \& Information. 2011;39:535-52.

[69] Armitage P, Godoy-Shimizu D, Steemers K, Chenvidyakarn T. Using Display Energy Certificates to quantify public sector office energy consumption. Building Research \& Information. 2015;43:691-709. [70] Hong S, Steadman P. An analysis of Dispaly Energy Certificates for Public Buildings, 2008 to 2012. In: CIBSE, editor.: UCL Energy Institute; 2013.

[71] Daly D, Cooper P, Ma Z. Understanding the risks and uncertainties introduced by common assumptions in energy simulations for Australian commercial buildings. Energy and Buildings. 2014;75:382-93.

[72] SIMLAB. V2.2, Simulation environment for uncertainty and sensitivity analysis. Developed by the Joint Research Center of the European Commission. 2011. 